\title{
Nanotheranostics
}

2019; 3(1): 120-134. doi: 10.7150/ntno.28468

Research Paper

\section{Nanomedicine-Assisted Combination Therapy of NSCLC: New Platinum-Based Anticancer Drug Synergizes the Therapeutic Efficacy of Ganetespib}

\author{
Jyothi Kallu' ${ }^{1}$, Tuhina Banerjee ${ }^{1}$, Shoukath Sulthana ${ }^{1}$, Saloni Darji ${ }^{1}$, Ryan Higginbotham ${ }^{1}$, Christina \\ Fletcher ${ }^{1}$, Nikolay N. Gerasimchuk ${ }^{2}$, Santimukul Santra ${ }^{1 \times}$ \\ 1. Department of Chemistry, Pittsburg State University, 1701 S. Broadway Street, Pittsburg, Kansas 66762, United States. \\ 2. Department of Chemistry, Missouri State University, 901 S. National Ave, Springfield, Missouri 65897, United States. \\ $\triangle$ Corresponding author: Santimukul Santra, Ph.D., Associate Professor. Department of Chemistry, Pittsburg State University, 1701 S. Broadway Street, \\ Pittsburg, Kansas 66762, United States. Phone: 620-235-4861, Fax: 620-235-4003. Email: ssantra@pittstate.edu \\ (C) Ivyspring International Publisher. This is an open access article distributed under the terms of the Creative Commons Attribution (CC BY-NC) license \\ (https://creativecommons.org/licenses/by-nc/4.0/). See http://ivyspring.com/terms for full terms and conditions.
}

Received: 2018.07.11; Accepted: 2018.11.09; Published: 2019.02.11

\begin{abstract}
Purpose: K-RAS is the most common mutated oncogene associated with Non-Small-Cell Lung Cancer (NSCLC). So far, there are no promising chemotherapies for the direct inhibition of K-RAS, and considered to be undruggable. In this work, we have introduced a new platinum-based cyanoximate complex, $\operatorname{Pt}(\mathrm{MCO})_{2}$, as an anti-cancer drug to enhance the therapeutic efficacy of Hsp90 inhibitor drug, ganetespib for the combination therapy of NSCLC.

Methods: We have synthesized polyacrylic acid (PAA)-coated magnetic nanoparticles (MNPs) and used as drug delivery system. These MNPs were decorated with folic acid in order to target folate receptor-expressing NSCLC. The individual and combination of drugs as well as an optical dye Dil were co-encapsulated successfully inside the PAA-coating of MNPs to evaluate synergistic treatment option for NSCLC. The magnetic resonance (MR) and optical imaging modalities assisted for the monitoring drug loading and NSCLC treatment.

Results: To evaluate the therapeutic efficacy of these customized MNPs, various cell-based assays including cell viability, apoptosis and necrosis, cell migration, comet and ROS experiments were performed. Results showed minimal toxicity for functional MNPs with no therapeutic drug and more than $60 \%$ cell death within $48 \mathrm{~h}$ of treatment, when single drug was encapsulated. Importantly, more than $90 \%$ cells were dead when both drugs were delivered. Overall, the results indicated that the $\mathrm{Pt}(\mathrm{MCO})_{2}$ drug enhances the therapeutic efficacy of ganetespib by more than $30 \%$ toxicity towards the targeted treatment of NSCLC, while showed minimal toxicity to the normal healthy tissues.

Conclusion: We successfully developed new dual-modal magnetic nanomedicines for the rapid and controlled release of combination of drugs for the effective treatment of NSCLC. The MR and fluorescence modalities help monitoring the delivery of drugs, where the new platinum-based drug $\mathrm{Pt}(\mathrm{MCO})_{2}$ synergizes the therapeutic efficacy of ganetespib.
\end{abstract}

Key words: platinum-based cyanoximate complex, ganetespib, Non-Small-Cell Lung Cancer

\section{Introduction}

Lung cancer is one of the leading cause of death worldwide. According to the American Cancer Society, NSCLC has a greater prevalence in men than women, and is the more common cancer type over
SCLC. ${ }^{1}$ NSCLC is highly metastatic and unresponsive to the conventional chemotherapeutics due to inappropriate accumulation of drug in the tumor, high toxic profiles to the normal cells and multi-drug 
resistance (MDR). ${ }^{2}$ Recently, nanoparticle-based theranostics have been employed for the targeted treatment of solid tumors to increase the efficacy of conventional anti-cancer agents and to alleviate their toxic effects as well. There are many nanotechnology-based drug delivery systems are available, including, polymeric, ${ }^{3,4}$ metallic (iron oxide, cerium oxide, silica, platinum and gold $)^{5-12}$ and viral nanoparticles. ${ }^{13,14}$ The advent of personalized nanomedicine has opened up new opportunities for the timely diagnosis and targeted treatment of cancer. ${ }^{15,16}$ Beyond cancer drug delivery, nanoparticles can also be used in other applications, including magnetic resonance imaging, ${ }^{8}$ pathogen detections, ${ }^{9}$ optical imaging, ${ }^{8}$ and DNA and gene delivery. ${ }^{6}$ The applications of the nanotechnology-based drug delivery systems in cancer therapies has been very successful due to their size in nanometer scale, allowing for the effective clearance by the kidney and lungs, enhanced retention time in blood circulation and therefore, effective delivery of drugs to the tumor. As a whole, nanoscale delivery system offers a great homing for anti-cancer agents and protects the drug from releasing outside the target site. Therefore, it controls accumulation of drugs at the tumor site, pharmacokinetic and dynamic parameters, and toxic effects towards the treatment. ${ }^{17,18}$ The standard course of treatment for patients with advanced NSCLC often includes combination therapy using more than one therapeutic drugs. The main advantage of combination therapy is the synergistic action of two or more drugs, targeting broad spectrum of tumorigenesis mechanisms, and results in fewer side effects. ${ }^{19-21}$ However, repeated failure of these therapies due to MDR, poor bioavailability and severe side effects indicated that there is a need for suitable drug combinations and delivery system. In the present study, we aimed to use two different drugs with specific mechanism of action in order to enhance therapeutic action. One of them is ganetespib (GT), a heat shock protein 90 (Hsp90) inhibitor, and the other is a new platinum-based drug, platinum cyanoximate complex $\mathrm{Pt}(\mathrm{MCO})_{2}(\mathrm{Pt})$, an antineoplastic therapeutic agent. The proposed drug mechanisms of action is highlighted in Figure 1. The latter compound belongs to a series of new cytotoxic platinum and palladium-based compounds with cyanoximes-based ligands that have demonstrated significant in vitro cytotoxicity against human cancer cells. ${ }^{10,22,23}$ The abbreviation for MCO stands for 'cyanoxime anion: 2-oximino-2-cyano-N-morpholyl-acetamide, $\mathrm{C}_{7} \mathrm{H}_{8} \mathrm{~N}_{3} \mathrm{O}_{3}{ }^{-}$.

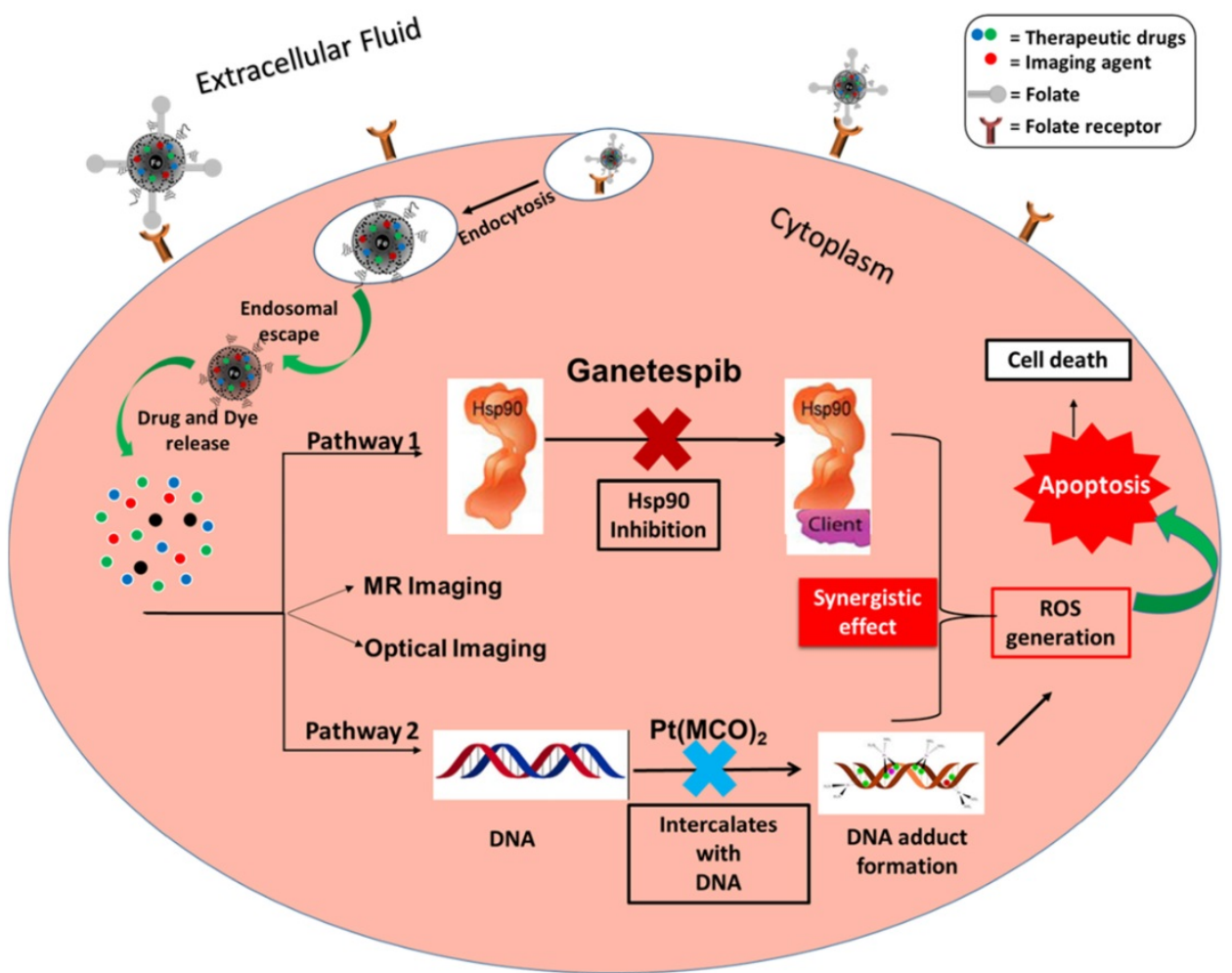

Figure 1. Schematic representation of the two different pathways of the proposed combination approach for the targeted treatment of NSCLC. Ganetespib, a Hsp 90 inhibitor, down-regulates tumorigenesis process by blocking $\mathrm{Hsp} 90$ chaperone. On the other hand, $\mathrm{Pt}(\mathrm{MCO})_{2}$, a new platinum-based antineoplastic drug inhibits DNA replication by forming DNA adduct. The released Dil dye and iron oxide would provide optical and MR imaging modalities, respectively. 
Cisplatin, carboplatin and oxaliplatin are widely used as platinum-based antineoplastic therapeutic agents for the treatment of NSCLC. ${ }^{19-21}$ It mainly acts by intercalating with DNA, forming DNA adducts inside the nucleus, which kills the highly proliferating cancer cells. This mechanism also increases intracellular reactive oxygen species (ROS) stress. However, these platinum-based drugs have drawbacks including severe kidney and liver side effects, which develop drug-resistance towards many cancers and poor solubility. This indicates that the conventional platinum-based drugs are not safe to be used as first-line therapeutics, suggesting that there is a need for new generation platinum-based chemotherapeutic. To this end, a novel 1-D polymeric, $\mathrm{Pt}$ is introduced potentially to overcome the problems with Pt-based drug resistance, side effects and solubility.22-24

The second point of interest, Hsp90 is a molecular chaperone controls many signaling pathways and protein kinases (client proteins), which involves in the tumorigenesis process. Hsp90 inhibitors are drugs, which prevent tumorigenesis process by blocking Hsp90 chaperone, resulting in down regulation of client proteins. Ganetespib, a known Hsp90 inhibitor, effectively suppresses tumors, which when applied with Pt could potentially overcome MDR. ${ }^{25-28}$

In this work, we have used Pt as a potential new anti-cancer drug and its therapeutic efficacy was evaluated using MNPs as drug delivery system. The anti-tumor activity of $\mathrm{Pt}$ was compared with that of cisplatin (cis-diaminodichloroplatinum, CDDP). In addition, Hsp90 inhibitor, GT, was used along with Pt to evaluate the synergistic effect on NSCLC treatment. Herein, we have formulated a novel, folate decorated, DiI dye, GT and Pt co-encapsulating MNPs for the imaging and effective treatment of NSCLC. The effective loading of these cargos and the NSCLC targeting was monitored by MR and optical imaging, respectively. The PEGylation of MNPs further enhanced its aqueous stability and bioavailability. The use of Pt drug, which would help to improve the targeted therapeutic efficacy of GT. Taken together, this work would develop new magnetic nanotheranostics for the multiparametric imaging and effective combination therapy of NSCLC in the clinical settings.

\section{Results and Discussion}

\section{Synthesis and characterizations of iron oxide-based magnetic nanoparticles (MNPs)}

Polyacrylic acid (PAA)-coated, superparamagnetic iron oxide nanoparticles were synthesized using water-based precipitation method as described in our previously reported method ${ }^{29}$ and detailed in the experimental section. Briefly, a mixture of an acidic solution of iron salts $\left(\mathrm{FeCl}_{3} \cdot 6 \mathrm{H}_{2} \mathrm{O}\right.$ and $\left.\mathrm{FeCl}_{2} \cdot 4 \mathrm{H}_{2} \mathrm{O}\right)$ was precipitated in $\mathrm{NH}_{4} \mathrm{OH}$ and followed by addition of PAA solution. The iron concentration was calculated using "iron digestion method"29,30 and was found to $[\mathrm{Fe}]=4.2 \times 10^{-3} \mathrm{~mol}$. The size of the synthesized MNPs were obtained using dynamic light scattering (DLS) measurement and the average diameter was found to be $68 \pm 2 \mathrm{~nm}$, as shown in Figure 2A. The overall size of MNPs was measured in triplicates. The size of the magnetic core was determined using transmission electron microscope (TEM) and found to be $8 \pm 3 \mathrm{~nm}$ (Scale bar: $100 \mathrm{~nm}$. Inset: Figure 2A). These results confirmed the presence of thicker $(\sim 30 \mathrm{~nm})$ PAA coating in our synthesized MNPs (1), indicated the possibility of cargo encapsulation in higher concentrations. The presence of PAA polymer coatings on MNPs were confirmed by the appearance of carbonyl stretching band at $1656 \mathrm{~cm}^{-1}$ using FT-IR spectroscopy (black line, Figure 2B). Successful coating of PAA polymer was further confirmed by observing negative zeta potential value $\zeta=-31 \mathrm{mV}$ (SI, Figure S1).

\section{Functionalization of MNPs and characterization}

Surface carboxylic acid groups of PAA-coated MNPs $\left(\mathbf{1},[\mathrm{Fe}]=4.2 \times 10^{-3} \mathrm{~mol}\right)$ were PEGylated using polyethylene glycol $\left(\mathrm{NH}_{2}\right.$-PEG-COOH, $\mathrm{M}_{\mathrm{w}}=600 \mathrm{Da}$, $10.0 \mathrm{mmol}$ ) polymer and water-based EDC/NHS (10.0 mmol) carbodiimide chemistry. ${ }^{29}$ PEGylation has been done to increase the stability and for longer circulation in blood of MNPs. ${ }^{31-33}$ After magnetic purification, the dialyzed PEGylated MNPs are then propargylated using propargylamine and the EDC/NHS-based carbodiimide chemistry, as described earlier. The resulting PEGylated and propargylated MNPs (3, Scheme 1, $[\mathrm{Fe}]=3.8 \times 10^{-3}$ $\mathrm{mol})$ were then purified and functionalized with folic acid using the "Click" chemistry. $29,34-36$ Folic acid is a folate receptor targeting ligand, and therefore, this conjugation would facilitate targeting folate-receptor expressing NSCLC using our folate-decorated MNPs. Azide-functionalized folic acid $(10.0 \mathrm{mmol})$ is synthesized as described in the supporting information (Scheme S1) and the "Click" chemistry was performed with MNPs $3\left(4 \mathrm{~mL}, 3.8 \times 10^{-3} \mathrm{~mol}\right)$ in the presence of $\mathrm{CuI}$ catalyst $(2.0 \mu \mathrm{M})$. The resulting folate functionalized MNPs (4a and 5a, Scheme 1) were purified using magnetic column and dialysis membrane before detailed characterizations, and the iron concentration was calculated $[\mathrm{IO}]=3.1 \times 10^{-3} \mathrm{~mol}$. The presence of folate groups on the surface of MNPs 
were confirmed by UV-Vis and fluorescence spectrophotometric analyses. The characteristic UV absorption maxima at $360 \mathrm{~nm}$ (Figure 2C) confirmed the presence of folate groups on the surface of MNPs and the fluorescence band at $455 \mathrm{~nm}$ further indicated successful conjugation of folic acids (Figure 2D).

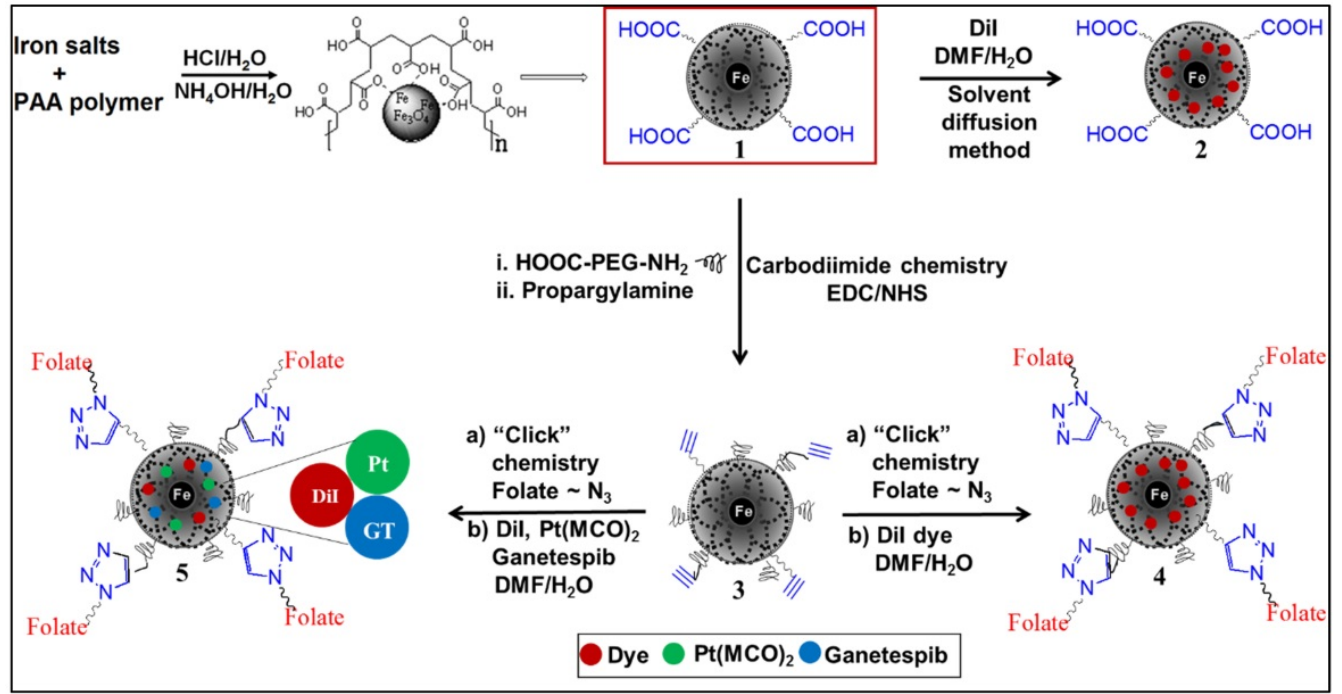

Scheme 1: Schematic representation of the synthesis of functional magnetic nanoparticles (MNPs). MNPs (1) were synthesized by "water-based precipitation method" and the PEGylated and propargylated MNPs (3) were synthesized using EDC/NHS carbodiimide chemistry. "Click" chemistry has been used to functionalize the nanoparticles with folic acid (4a and 5a). "Solvent diffusion method" was used to co-encapsulate Dil dye and anti-cancer therapeutic agents GT and Pt to formulate desired functional MNPs (4b and $\mathbf{5 b}$ ).
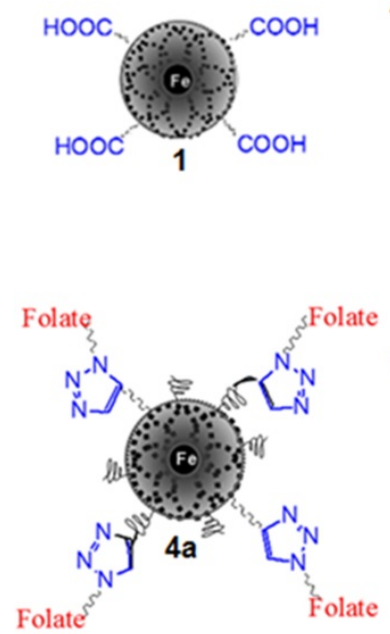

C)
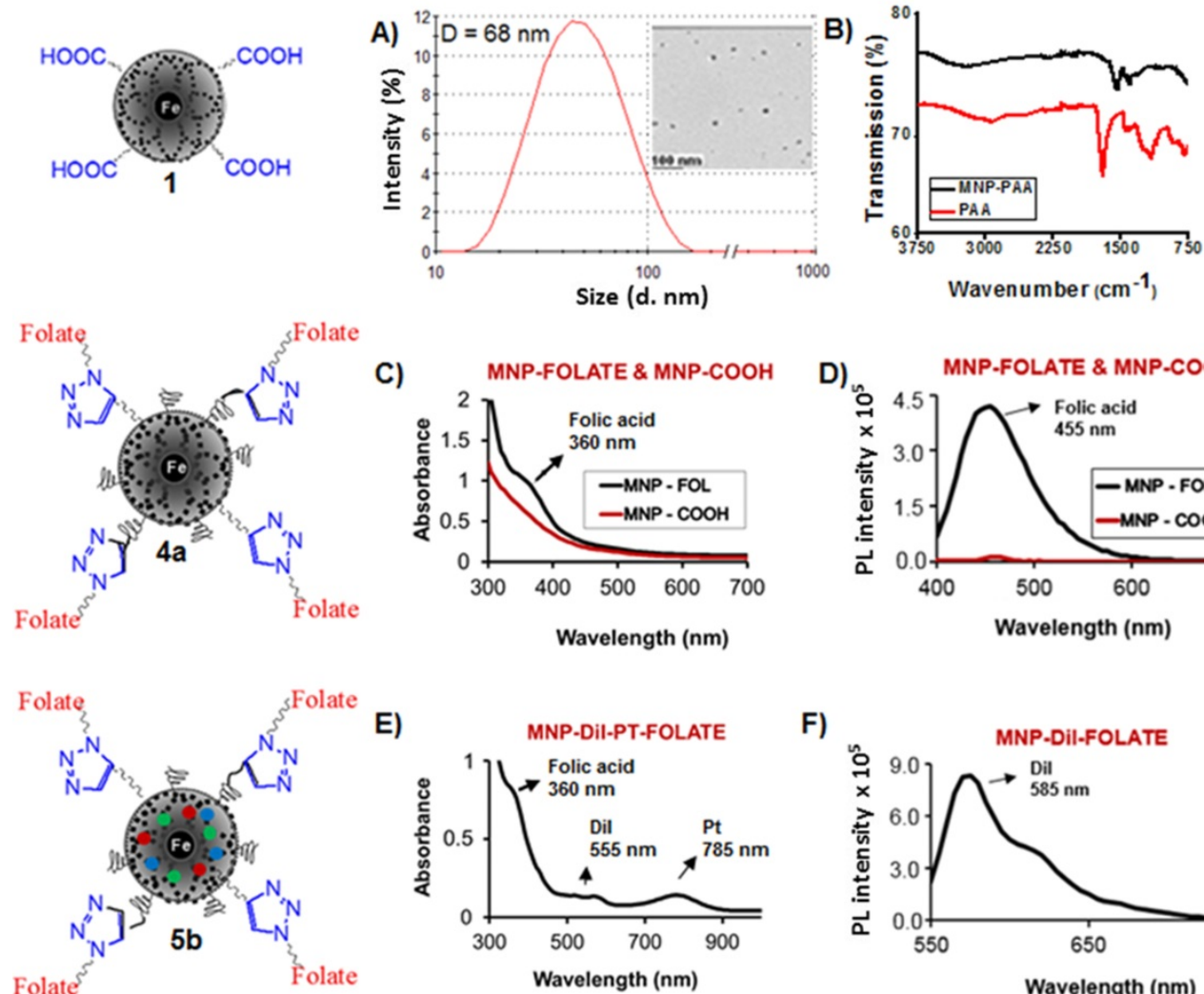

E)

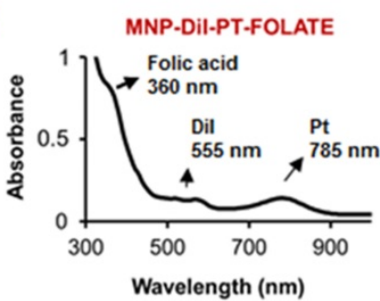

D)

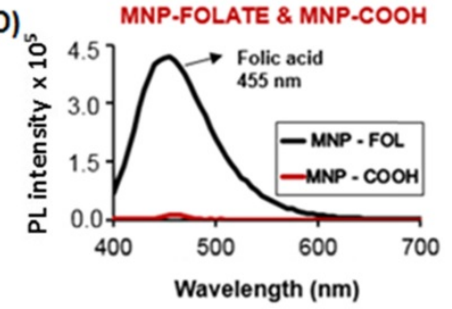

F)

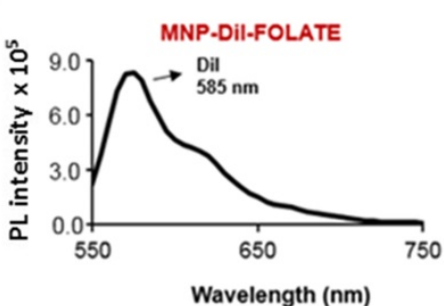

Figure 2: Characterizations of functional MNPs. A) Determination of the size (diameter D) using dynamic light scattering (DLS) showing the hydrodynamic diameter is $68 \pm 2 \mathrm{~nm}$. Inset: Transmission Electron Microscopy (TEM) image of the corresponding nanoparticles, scale bar $100 \mathrm{~nm}$, showed iron oxide core size of $8 \pm 3 \mathrm{~nm}$. B) The presence of PAA coatings in MNPs $(1)$ was confirmed by FT-IR spectrum. C) UV-Vis absorption $\left(\lambda_{\text {abs }}=360 \mathrm{~nm}\right)$ and $\left.\mathbf{D}\right)$ fluorescence emission spectra $\left(\lambda_{\text {max }}=\right.$ $455 \mathrm{~nm}$ ) confirms the presence of folic acid. E) UV-Vis absorption spectrum of cargos encapsulating folate decorated MNPs (5b). Presence of bands at $360 \mathrm{~nm}, 555$ $\mathrm{nm}$, and $785 \mathrm{~nm}$ indicates presence of folic acid, Dil dye and Pt, respectively. F) Fluorescence emission spectrum of the functional $\mathrm{MNPs}\left(\mathbf{5 b}, \lambda_{\text {max }}=585 \mathrm{~nm}\right)$ confirmed for the presence of optical Dil dye. 


\section{Encapsulation of drugs and dye into the MNPs and characterization}

Modified solvent diffusion method ${ }^{26,29}$ was used to encapsulate dialkylcarbocyanine lipophilic fluorescent dye (DiI) and therapeutic drugs Pt and GT within the hydrophobic PAA polymer coating of MNPs. The new platinum drug, $\mathrm{Pt}$, was previously synthesized 22,23 and a brief synthetic protocol and characterization are outlined in the supporting information (Scheme S2, and Figure S2 and S3). The successful encapsulation of cargos inside the nanoparticle depends on several important parameters including hydrophobicity, diameter and thickness of the PAA coating. The lipophilic DiI dye that fluoresce at $585 \mathrm{~nm}$ and drugs were incorporated with high encapsulation efficiency $\left(\mathrm{EE}_{\mathrm{DiI}}=88 \%, \mathrm{EE}_{\mathrm{GT}}\right.$ $\left.=82 \%, \mathrm{EE}_{\mathrm{Pt}}=74 \%\right)$ as described in the experimental section. These resulting functional MNPs $(5 \mathbf{b}$, Scheme $\mathbf{1},[\mathrm{Fe}]=2.5 \times 10^{-3} \mathrm{~mol}$ ) were purified using magnetic column and eluted using PBS, $\mathrm{pH}=7.4$ and detailed stability studies were performed by collecting DLS and T2 MR data with time (SI, Table S1-S2 and Figure $\mathbf{5 b})$. The effective encapsulations of cargos were confirmed by spectrophotometric and magnetic relaxation (MR) techniques. Presence of Dil dye was confirmed by UV-Vis $\left(\lambda_{\text {abs }}=555 \mathrm{~nm}\right)$ and fluorescence band $\left(\lambda_{\max }=585 \mathrm{~nm}\right.$, Figure 2E and 2F). The presence of therapeutic agent $\mathrm{Pt}$ was confirmed by collecting absorbance band at $785 \mathrm{~nm}$ (Figure 2E). However, the presence of non-fluorescent therapeutic agent GT was tracked by MR study by using bench top magnetic relaxometer. ${ }^{37,38}$ Encapsulation of GT in the PAA coatings of MNPs leads to change in spin-lattice and spin-spin magnetic relaxation times ( $\Delta \mathrm{T} 1$ and $\Delta \mathrm{T} 2 \mathrm{~ms})$ due to replacement of neighboring water molecules from the vicinity of iron oxide core. This increase in magnetic relaxation times confirms the loading of GT inside the nanoparticles and the results are displayed in Figure 3A-3B.

\section{Drug release studies}

Drug release studies were performed using dynamic dialysis method ${ }^{29,38}$ at two different $\mathrm{pH}$, acidic $\mathrm{pH} 6.0$ and physiological $\mathrm{pH}$ 7.2. It is hypothesized that at $\mathrm{pH} 6.0$, the PAA polymer coatings of MNPs will be disrupted or swelled and consequently, the encapsulating cargos will be released, which demonstrate the fate of MNPs inside the tumor. The release of $\mathrm{Pt}$ drug was monitored time to time using a plate reader and measuring $\mathrm{UV} / \mathrm{Vis}$ data at $785 \mathrm{~nm}$. As shown in Figure 3C, 60\% of Pt drug was released within $6 \mathrm{~h}$, when dialyzed at $\mathrm{pH}$ 6.0. In contrast, minimum release of $\mathrm{Pt}$ drug (4\%) was observed at $\mathrm{pH}$ 7.2. These results indicated that our functional MNPs are stable at physiological $\mathrm{pH}$, whereas, it would deliver the encapsulating cargos within the acidic microenvironment of cancer cells. In addition, the release of GT was monitored using MR technique as release of cargo would reduce the T1 and T2 MR signals, this also includes DiI dye and Pt drug release. However, we have demonstrated GT release study using MR technique as it does not fluoresce. MNPs aliquots were collected directly from inside the dialysis bag and both $\mathrm{T} 1$ and $\mathrm{T} 2 \mathrm{MR}$ were collected at different time points. As encapsulating GT released, water molecules replaced, and therefore, significant change in both T2 and T1 MR signals were observed (Figure 3D and 3E). These MR studies showed 50\% change in the T1 and T2 signals within 6 to $7 \mathrm{~h}$ of incubation, which indicated for the equivalent amount GT release. These release studies further indicated for the drug delivery capability of our MNPs in cancer cells, whereas minimal release is expected in healthy cells $(\mathrm{pH}=7.2)$. In addition, as the internalization mechanism is receptor-mediated, we expect no to minimal drug delivery in healthy cells. In conclusion, these experiments suggested that our functional MNPs are stable at physiological $\mathrm{pH}$ and deliver cargos when inside the tumor's acidic environment.

\section{In vitro cell viability study: MTT assay}

The biocompatibility and safety profile of drug delivery systems are key aspects for its clinical translation. We have studied the biocompatibility and cytotoxicity profiles of parental and cargos loaded folate MNPs in lung cancer A549 (NSCLC, folate receptor + ) and Chinese Hamster Ovarian $(\mathrm{CHO}$, folate receptor -) cells using MTT assay protocols. ${ }^{29,39}$ The results demonstrated that the parent MNPs (MNP-DiI-FOL) with no drugs showed minimal toxicity in both the cell lines as reflected by less than $5 \%$ cell death in $48 \mathrm{~h}$ of incubation (Black lines, Figure 4A and 4B). These results indicated for the biocompatibility of our folate functionalized MNPs. Next, Cisplatin (CDDP), GT, Pt and combination of Pt and GT loaded nanoparticles were tested for their cytotoxicity in these cell lines. In A549 cells, functional folate MNPs with single drug (MNP-DiI-Pt-FOL, MNP-DiI-CDDP-FOL and MNP-DiI-GT-FOL, $30 \mu \mathrm{L}$, $[\mathrm{Fe}]=2.5 \times 10^{-3} \mathrm{~mol}$ ) showed comparable cytotoxicity. Especially, the new polymeric Pt drug containing MNPs (MNP-DiI-Pt-FOL) exhibited slightly higher cytotoxicity compared to other drugs, CDDP and GT-containing MNPs. This important finding demonstrates for the development of new antineoplastic therapeutic agent, potentially to overcome MDR and cytotoxic effect of conventional Pt-based drugs. In a combination therapy, GT and Pt-co-encapsulating MNPs $\left(30 \mu \mathrm{L},[\mathrm{Fe}]=2.5 \times 10^{-3}\right.$ 
mol) were used and a synergistic cytotoxic effect was observed with severe cell death. Pt, CDDP, GT and Pt/GT-encapsulating MNPs showed 65\%, 60\%, 50\% and more than $90 \%$ cell death, respectively (Figure 4A). The higher cellular cytotoxicity of the combination therapy indicated that the therapeutic efficacy of GT was enhanced by the new platinum drug. On the other hand, these functional MNPs (30 $\mu \mathrm{L},[\mathrm{Fe}]=2.5 \times 10^{-3} \mathrm{~mol}$ ) were incubated with folate receptor negative $\mathrm{CHO}$ cells. Under similar conditions, these MNPs showed minimal cytotoxicity to the $\mathrm{CHO}$ cells. This is due to lack of internalizations of the MNPs into the CHO cells, and showed less than $5-10 \%$ cell death in the period of $48 \mathrm{~h}$ (Figure 4B). In summary, these results suggested that our newly designed functional MNPs are capable of targeting NSCLC, whilst showing minimum toxicity to healthy cells. In addition, this would potentially address the current failure of NSCLC treatment using GT.40
A)

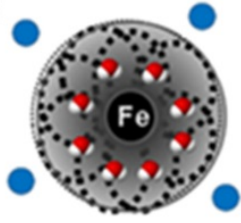

Low T2/T1

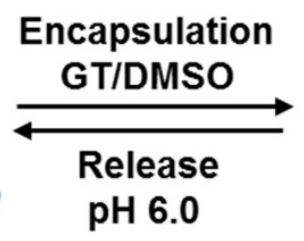

Water molecule

GT

C)

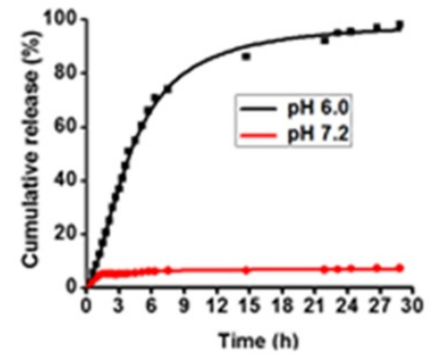

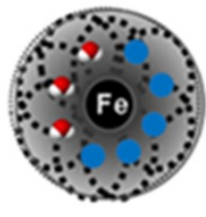

High T2/T1

D)

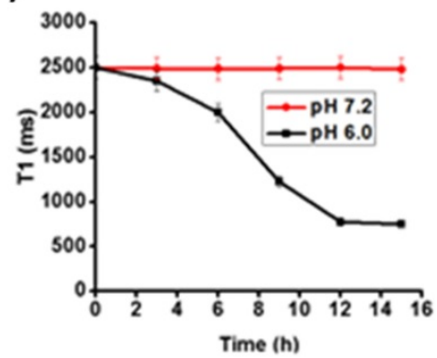

B)

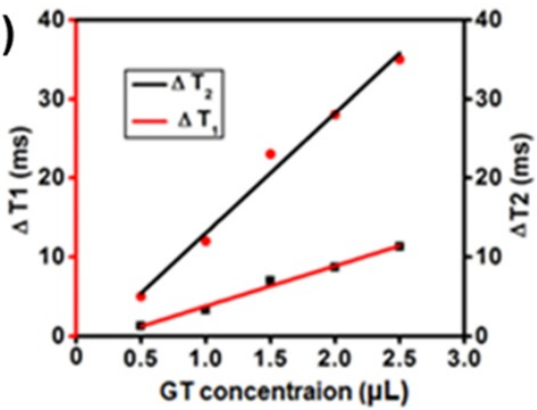

E)

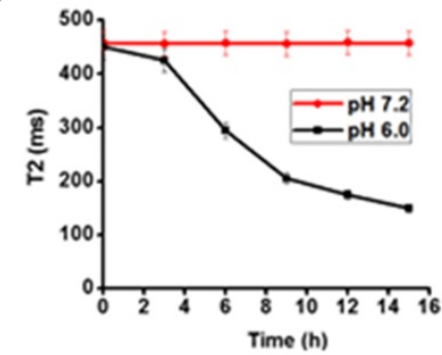

Figure 3: Effective encapsulation of GT tracked by collecting $\Delta M R$ values. A) The schematic representation of the mechanism of displacement of neighboring water molecules as a result of GT encapsulations and the corresponding MR changes. B) Concentration dependent increase in $\Delta \mathrm{T} 2$ and $\Delta \mathrm{T} 1$ as the amount of GT (0.5-2.5 $\mu \mathrm{L}, 5.0 \mathrm{mmol}$ ) encapsulation increases. Controlled drug release experiments: $\mathbf{C}$ ) Pt drug release from the functional $\mathrm{MNPs}$ at $\mathrm{pH} 7.2$ and 6.0 . As the drug releases in acidic $\mathrm{pH}$ 6.0, UV absorption maxima at $\lambda_{\mathrm{abs}}=785 \mathrm{~nm}$ increases with time. However, no or minimal release of encapsulating Pt was observed at neutral phosphate buffer ( $\mathrm{pH}$ 7.2) solution. D) The GT release study was performed using MR technology. Changes in the T1 and E) T2 MR times were observed in the presence of acidic $\mathrm{pH}$ (6.0) only. Represented data are shown as mean of \pm standard error. Each experiment was performed in triplicate.
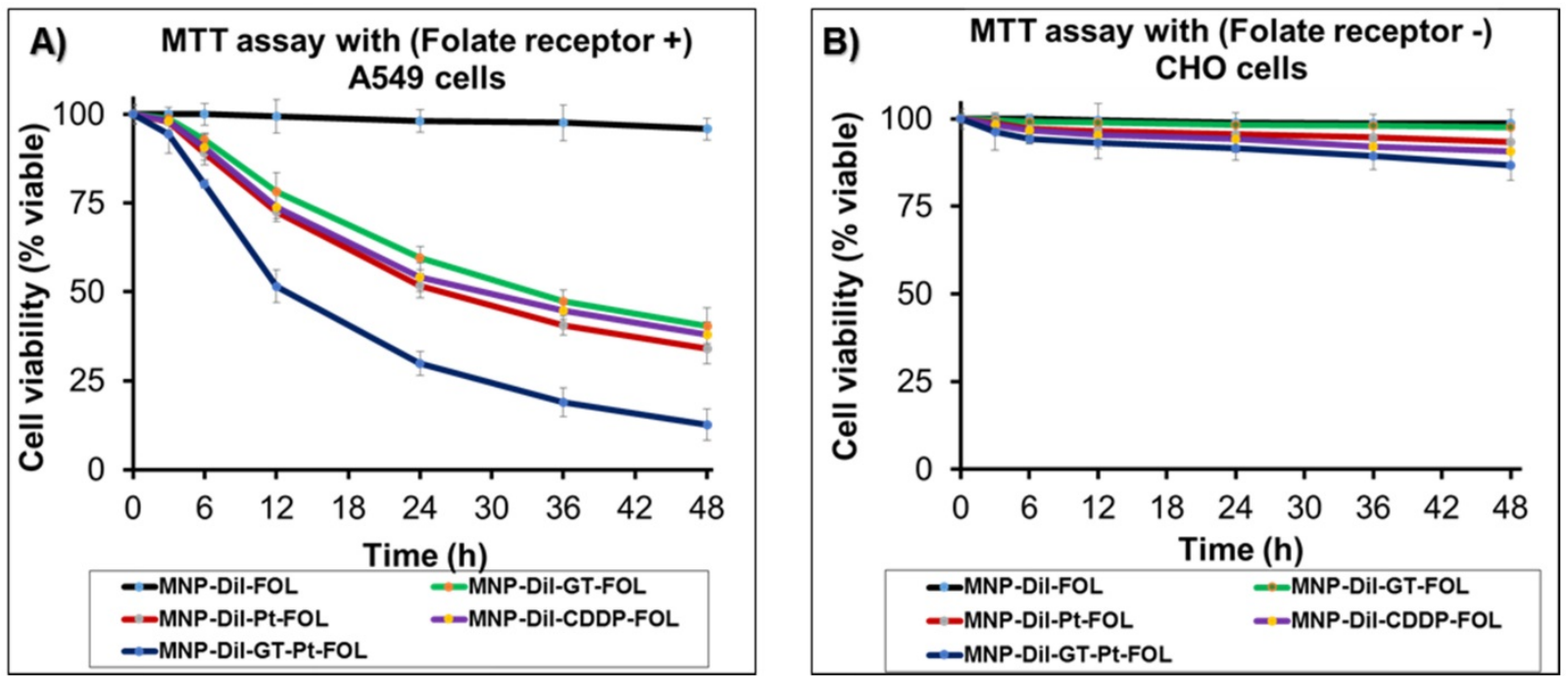

Figure 4: A) Assessment of cytotoxicity of different functional MNPs in folate receptor positive A549 cells: MNPs-Dil-FOL with no drug, MNPs with single drug: CDDP, GT, Pt and combination of drugs [Pt and GT]. MNPs-Dil-FOL with no drug showed minimal toxicity to the cells. Folate MNPs with single drug has showed nearly 50-65\% toxicity. However, folate MNPs with combination of drugs [GT and Pt] have killed more than $90 \%$ of cells in 48 h. B) Cellular toxicity of functional MNPs with folate receptor negative $\mathrm{CHO}$ cells: Minimal toxicity was observed in $\mathrm{CHO}$ cells due to the lack of folate receptors on the surface and effective internalizations of the functional MNPs. Represented data are shown as mean of \pm standard error. Each experiment was performed in triplicate. 


\section{Intracellular uptake of cargos-loaded MNPs via receptor-mediated endocytosis}

To examine the uptake of MNPs into NSCLC by endocytosis, folate-decorated DiI dye encapsulating MNPs $\left(4 \mathbf{b}, 75 \mu \mathrm{L},[\mathrm{Fe}]=3.1 \times 10^{-3} \mathrm{~mol}\right)$ were incubated in the presence of metabolic inhibitors: sodium azide $(10 \mathrm{mM})$ and 2-deoxyglucose $(25 \mathrm{mM})$ at $37^{\circ} \mathrm{C}$ as well as incubated at $4{ }^{\circ} \mathrm{C}$ for $24 \mathrm{~h}$. Fluorescence microscopy was used to evaluate the internalization results using A549 cells (10,000 cell/well). Minimal fluorescence was measured from the cells incubated in the presence of inhibitors and at $4{ }^{\circ} \mathrm{C}$. (Figure 5A) The decrease in MNPs uptake under these conditions indicated that the folate $\mathrm{MNP}^{\prime} \mathrm{s}$ internalization depends on the energy (ATP-related) and temperature status of A549 cells. This is due to the fact that the metabolic inhibitors, sodium azide and 2-deoxyglucose, create an ATP-depleted environment inside the cell. ${ }^{41}$ These results indicated for the active internalization of MNPs via endocytosis, 42,43 which was further confirmed by observing higher fluorescence from the cells incubated at $37{ }^{\circ} \mathrm{C}$. The extent of internalization was cross-validated by measuring fluorescence emission intensities from the MNPs internalized cells. The collected results corroborated the hypothesis of internalization mechanism and displayed in Figure 5B.
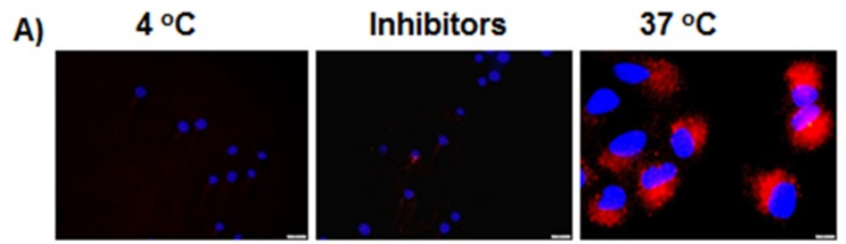

B)

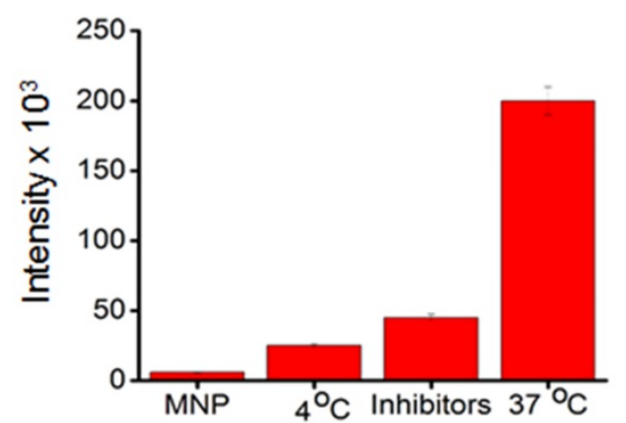

Figure 5: A) Determination of cellular internalization of folate-MNPs (4, Scheme 1). Minimal internalizations at low temperature and in the presence of metabolic inhibitors at $37 \circ \mathrm{C}$ indicated for the endocytosis mechanism (scale bar $20 \mu \mathrm{m}$ ). B) Quantification of cellular uptake of folate-MNPs via fluorescence intensity measurement using a plate reader. The fluorescence intensities from the MNPs incubated A549 cells were measured at $585 \mathrm{~nm}$. These results indicated for the endocytic internalization mechanism.

Selective uptake and cytotoxicity of functional MNPs using fluorescence microscopy
To further indicate the selective uptake of our folate conjugated functional MNPs in A549 cancer cells, we have used fluorescence microscopic technique for internalization experiments. We hypothesized that folate MNPs with drugs would be toxic to cancer cells (A549, FR +) but minimal to normal cells ( $\mathrm{CHO}, \mathrm{FR}-)$ due to lack of internalizations. Next, A549 cells (10,000 cell/well) were treated with carboxylated MNPs $(75 \mu \mathrm{L},[\mathrm{Fe}]=$ $2.5 \times 10^{-3} \mathrm{~mol}$ ) with combination of drugs (GT and $\mathrm{Pt}$ ) for $24 \mathrm{~h}$. As expected, due to the absence of folate group on the surface of MNPs, minimal internalizations with no effective cell death was observed (Figure 6A-6D). However, folate receptor-mediated internalization was confirmed by observing effective internalizations of MNPs-DiI-FOL $\left(5 \mathbf{a}, 75 \mu \mathrm{L},[\mathrm{Fe}]=2.5 \times 10^{-3} \mathrm{~mol}\right)$ with no drug in A549 cells (Figure 6E-6H). Next, we investigated for the therapeutic efficacy of our folate MNPs with combination of drugs. Interestingly, folate receptor-mediated endocytosis and mitotic cell arrest, leading to A549 cell death was observed when incubated with folate-decorated GT and Pt drugs encapsulating MNPs $\left(5 \mathbf{b}, 75 \mu \mathrm{L},[\mathrm{Fe}]=2.5 \times 10^{-3} \mathrm{~mol}\right)$ for 24 hours (Figure 6I-6L). These results corroborated our cytotoxicity assays and further indicated that the poor therapeutic efficacy of GT towards NSCLC treatment can be accelerated by using the proposed combination therapy approach using new platinum drug Pt. In contrast, no significant cellular internalizations and reduction in cell viability were observed when $\mathrm{CHO}$ cells $(10,000$ cell/well), which do not overexpress folate receptor, were incubated with folate MNPs $\left(5 \mathbf{b}, 75 \mu \mathrm{L}\right.$, [Fe] $\left.=2.5 \times 10^{-3} \mathrm{~mol}\right)$ with combination of drugs for $24 \mathrm{~h}$ (Figure 6M-6P). These results demonstrated that our folate MNPs carry the following important features: 1) non-toxic and biocompatible when no drug carried, 2) targeted drug delivery to cancer cells, minimizing toxicity to healthy cells and side effects, 3) can be used for optical and MR imaging of cancer, and 4) capable of delivering more than one drug for the combination therapy of cancer.

\section{Determination of mitochondrial and cytosolic ROS stress}

Next, we hypothesized that ROS (reactive oxygen species) is generated in A549 cells when incubated with $\mathrm{Pt}$ drug and combination of drugs ( $\mathrm{Pt}$ and GT) encapsulating MNPs. To determine and quantify the amount of ROS generation, we have used two different dyes, Mitosox $(5 \mu \mathrm{M})$ and DHE (Dihydroethidium, $32 \mu \mathrm{M}$ ) dyes, to track ROS in the mitochondria and cytoplasm, respectively. The images were captured from the corresponding tissue 
culture dishes (Figure 7A) and the ROS quantification has been done using imageJ software (Figure 7B). The results indicated that novel $\mathrm{Pt}$ complex drug, once released inside the cytoplasm, produced substantial amount of ROS radicals in cytoplasm as well as in mitochondria. This is due to fact that similar to cisplatin, Pt drug migrates and binds to mitochondrial DNA, producing ROS as shown in Figure 7A. Similarly, in the case of combination therapy, we have observed higher amount of ROS generation when compared to $\mathrm{Pt}$ alone and this is due to synergistic action. Note that minimal amount of ROS generation was observed from folate MNPs with no drugs, this is possibly due to the iron oxide-based "Fenton mechanism". ${ }^{44-46}$ To further confirm that the ROS generation was due to the incubation with drug-loaded nanomedicines and the potential reason for cell death, parallel experiments were carried out in the presence of $\mathrm{N}$-acetyl cysteine (NAC, $3.0 \mathrm{mM}$ ). The compound NAC is an antioxidant, known to identify ROS inducers and to inhibit ROS. The results indicated that the amount of ROS generation was substantially reduced in all experiment conditions in the presence of NAC. The ROS generation and the corresponding inhibition were quantified using image J software, as displayed in Figure 7B. Taken together, these experiments further indicated for the generation of ROS when therapeutic drug was delivered, which ultimately causes cancer cell death. $23,39.42$

\section{Examination of cell-death mechanisms: apoptosis and necrosis pathways}

Morphological and biochemical changes including flipping of phosphatidylserine (PS) and loss of membrane potential occur as a result of apoptosis, a programmed cell death, and in events through necrosis. ${ }^{47,48}$ In this study, these changes were examined by using Annexin V-FITC (green color for apoptotic cells) and Ethidium homodimer III (red color for necrotic cells) dyes. Cells were platted in tissue culture dishes $(10,000$ cell/well $)$ and treated with functional MNPs $\left(5 \mathbf{b}, 75 \mu \mathrm{L},[\mathrm{Fe}]=2.5 \times 10^{-3} \mathrm{~mol}\right)$ encapsulated with $\mathrm{Pt}, \mathrm{GT}$ and combination of these two drugs for $12 \mathrm{~h}$. Results indicated that cells treated with GT (Figure 8A-B) and Pt only MNPs (Figure 8C-D) showed increased number of apoptotic cells (A, green color) with very few necrotic ( $\mathbf{N}$, red color) and live cells (L, dim green). As expected, A549 cells incubated with combination drugs, Pt and GT, have also showed higher number of apoptotic cells (Figure 8E-F). These experiments indicated that our newly formulated drugs encapsulating nanomedicines prefer apoptotic programmed cell death pathway.

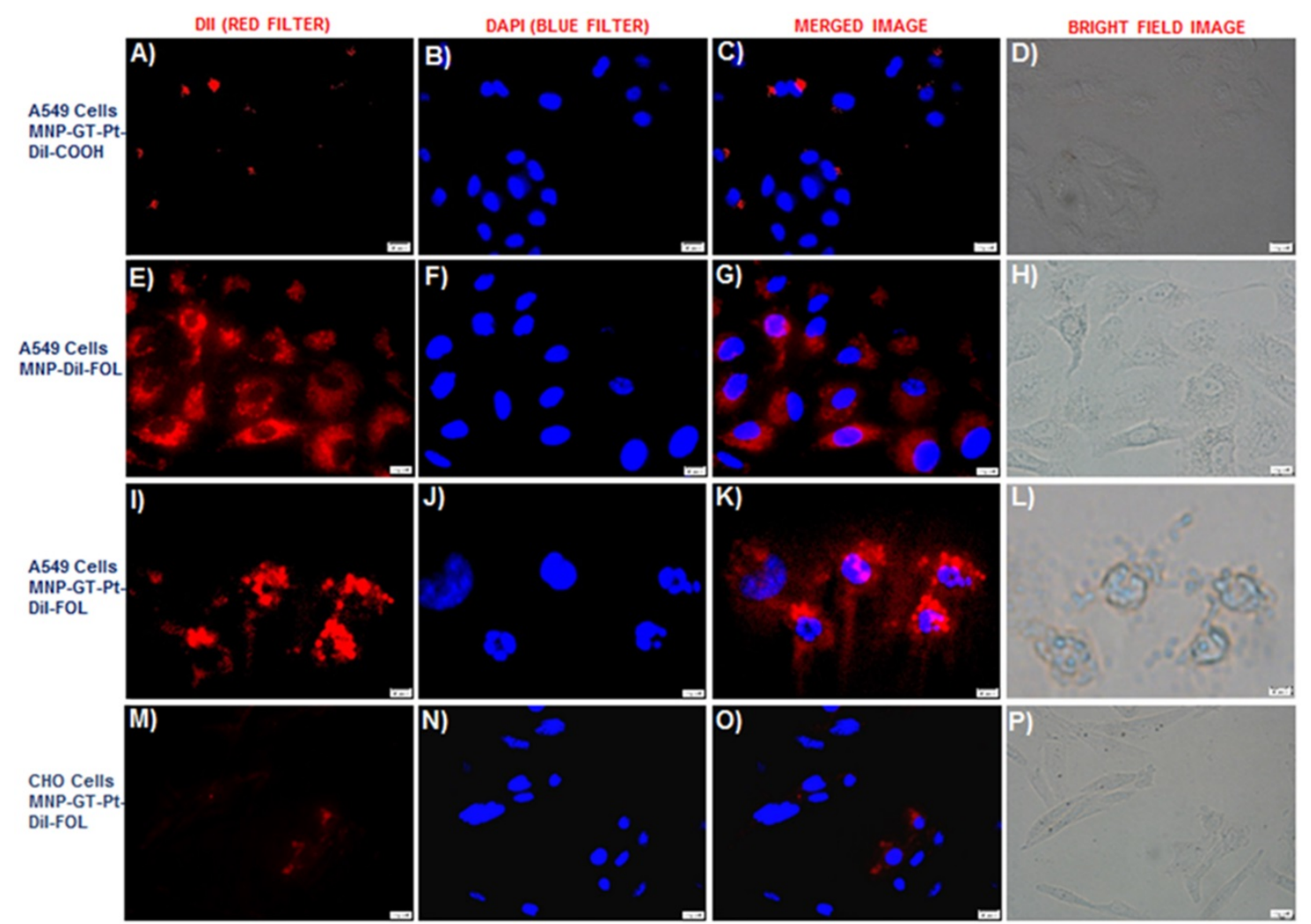

Figure 6: A-D) No or minimal internalization of carboxylated MNPs with combination of drugs were observed in A549 cells (scale bar $20 \mu \mathrm{m}$ ). E-H) Internalization of folate MNPs with no drugs were observed due to the folate receptor-mediated endocytosis. I-L) Cell death observed within $24 \mathrm{~h}$ when folate MNPs with combination of drugs incubated with A549 cells. M-P) Minimal internalization of folate MNPs with drugs were observed with CHO cells. Nuclei stained with DAPI (blue). Olympus fluorescence microscope IX73 was used with $40 x$ objective. 


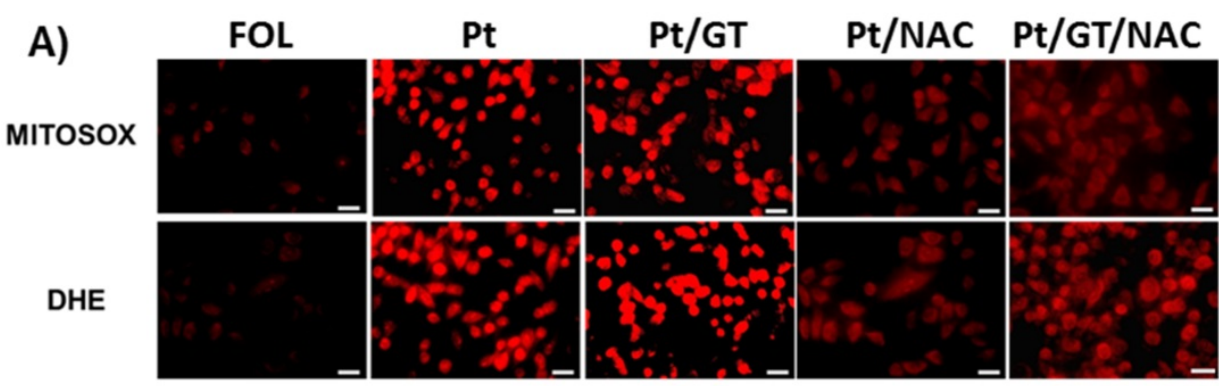

B)

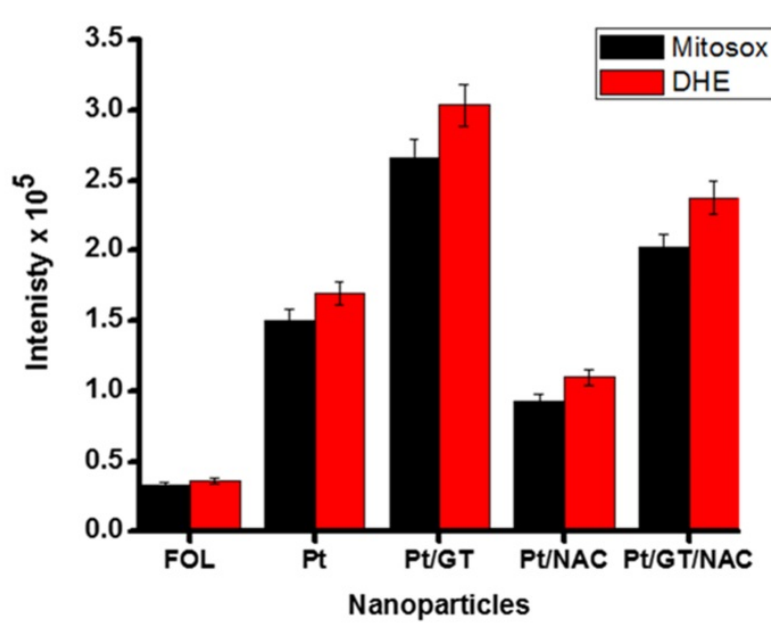

Figure 7: Determination and quantification of ROS in A549 cells (scale bar $20 \mu \mathrm{m}$ ). A) Generation of mitochondrial and cytoplasmic ROS in the presence of Pt and GT drug encapsulating MNPs $\left(\mathbf{5 b}, 75 \mu \mathrm{L}\right.$, [Fe] = $\left.2.5 \times 10^{-3} \mathrm{~mol}\right)$, which are labelled using Mitosox and DHE dyes, respectively. Presence of NAC (3.0 mM) inhibits the ROS generation. B) The amount of ROS generations were quantified directly from the corresponding fluorescence microscopic images using image software.
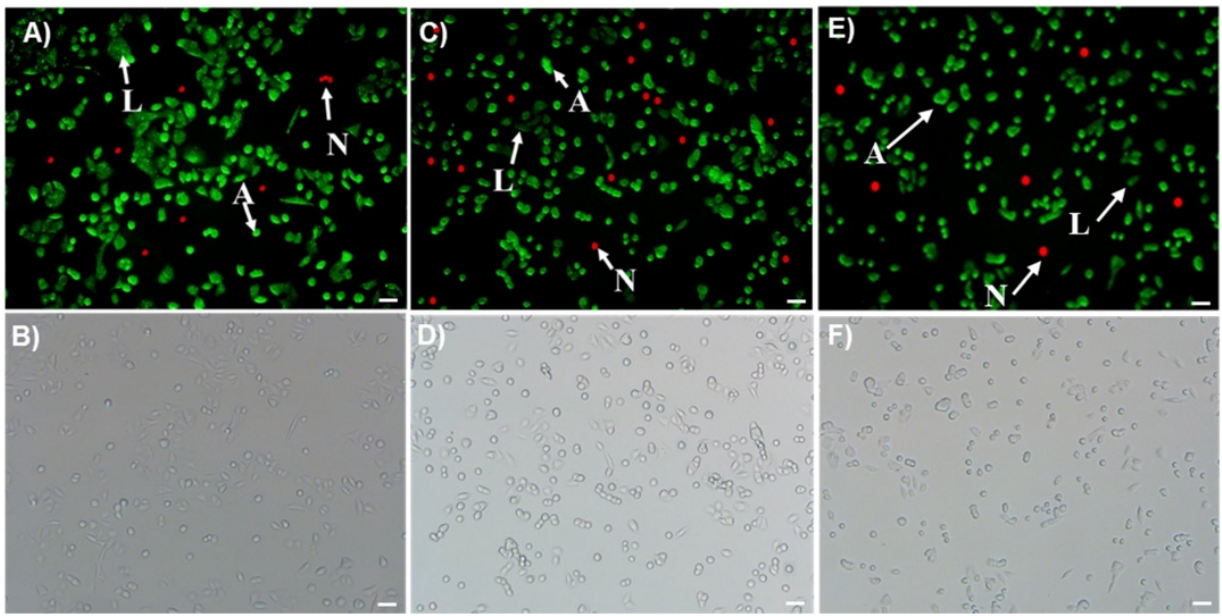

Figure 8: Determination of apoptosis and necrosis events in A549 cells after treatment with A-B) GT, C-D) Pt and E-F) combination of both Pt and GT drugs encapsulating MNPs (5b, $75 \mu \mathrm{L}$, [Fe] = $\left.2.5 \times 10^{-3} \mathrm{~mol}\right)$ for $12 \mathrm{~h}$ (scale bar $\left.20 \mu \mathrm{m}\right)$. A549 cells were then stained with Annexin V-FITC and Ethidium homodimer III. The cell images were taken using fluorescence microscope with FITC (green) and CY3 (red) filters. Green images for apoptotic (A), red images for necrotic cells (N) and the dim green images indicated for live cells (L).

\section{Transwell migration or invasion assay}

K-RAS driven NSCLC is known to be undruggable and highly metastatic. Advanced staging and high metastatic ability of NSCLC are the results of cell invasion from primary tumor site to other tissues or organs. ${ }^{49}$ In this study, we have investigated the effect of combination therapy using
GT and Pt drugs encapsulating MNPs in the migration of A549 cells using transwell migration assay kit from Millipore. The starved A549 cells were incubated with functional MNPs with and without drugs and allowed $24 \mathrm{~h}$ for migration. The migratory or invaded cells were quantified using CYQuant cell lysis buffer and using a plate reader $\left(\lambda_{\mathrm{em}}=560 \mathrm{~nm}\right)$. The results showed that highest fluorescence was 
observed from cells incubated with control MNPs with no drugs as highest number of cells migrated through the collagen layer. In contrary, very minimal fluorescence was observed from A549 cells incubated with experimental MNPs with drugs (Figure 9). This is due to the action of therapeutic agents on inhibition of migration process, and very few cells migrated to collagen layer. These results demonstrated that our combination therapy would prevent NSCLC metastasis effectively.

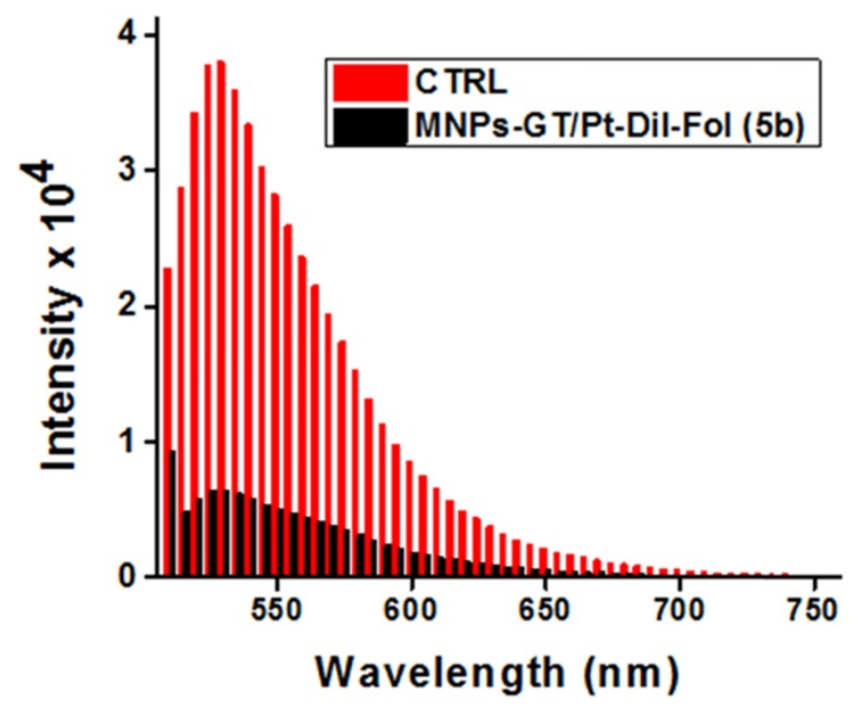

Figure 9: The effect of combination therapy on the A549 cell migration process and to evaluate the anti-metastatic effect of the combination therapy. Results indicated for minimal invasion of A549 cells in the presence of combination of drugs encapsulating MNPs.

\section{Comet assay}

The comet assay is widely used as standard in vitro technique for predicting the response of chemotherapeutic drugs in different cancer cells. ${ }^{50,51}$ In the current study, alkaline comet assay experiments were performed for the assessment of possible DNA damage induced by the $\mathrm{Pt}$ (Figure 10B) or with a combination of $\mathrm{Pt}$ and GT (Figure 10C) encapsulating MNPs $\left(5 \mathbf{b}, 60 \mu \mathrm{L},[\mathrm{Fe}]=2.5 \times 10^{-3} \mathrm{~mol}\right)$. Following the treatment of A549 cells on a 12-well plate $(8,000$ cells/well), different comet assay parameters including olive moment, tail moment and $\%$ of DNA in the tail were analyzed to quantify the extent of DNA damage. Olive moment indicates and measures smallest and broken pieces of DNA, while $\%$ tail DNA reflects DNA damage in the tail part and tail moment is the all broken DNA in the tail (Figure 10D). These three parameters are often used for scoring of comets and to determine the effect of drug treatment. Control experiments were also performed using MNPs with no drug $\left(5 \mathrm{a}, 60 \mu \mathrm{L},[\mathrm{Fe}]=2.5 \times 10^{-3}\right.$ mol, Figure 10A) and exhibited minimal DNA damage. As shown, A549 cells treated with Pt showed significant amount of DNA damage as reflected by higher values of olive and tail moment along with elevated percentage of tail DNA (Figure 10B). The extent of DNA damage was further enhanced with the combination drug treatment (Figure 10C).
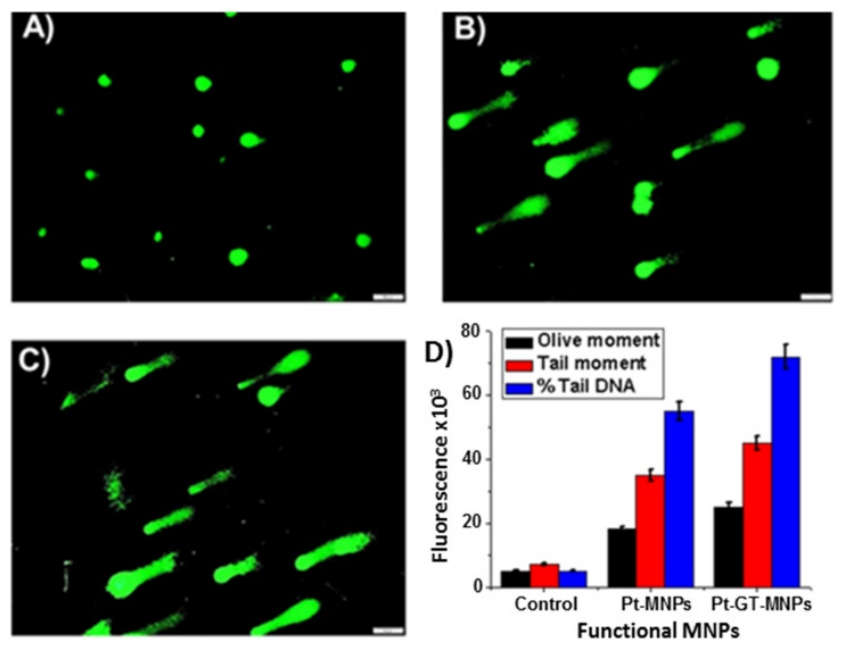

Figure 10: Comet assays were performed on $A 549$ cell line using functional $\operatorname{MNPs}\left(5,60 \mu \mathrm{L},[\mathrm{Fe}]=2.5 \times 10^{-3} \mathrm{~mol}\right)$ for $24 \mathrm{~h}$ (scale bar $\left.20 \mu \mathrm{m}\right)$. A) Control comet experiment was performed using MNPs with no drugs. Comet experiments using B) Pt-MNPs and C) combination of drugs Pt-GT-MNPs. D) Quantification of comet assay parameters, including olive moment, tail moment and \% tail DNA were calculated using ImageJ software. Represented data are shown as mean of \pm standard error. Each experiment was performed in triplicate.

\section{Experimental Section}

\section{Materials}

Ferric chloride hexahydrate $\left(\mathrm{FeCl}_{3} \cdot 6 \mathrm{H}_{2} \mathrm{O}\right)$, ferrous chloride tetrahydrate $\left(\mathrm{FeCl}_{2} .4 \mathrm{H}_{2} \mathrm{O}\right)$, hydrochloric acid and ammonium hydroxide were obtained from Fischer Scientific. DMF, DMSO, 3-(4, 5-dimethylthiazol-2-yl)-2,5-diphenyltetrazolium bromide (MTT), N-hydroxysuccinimide (NHS), polyacrylic acid (PAA), propargylamine (PA) and other chemicals were purchased from Sigma-Aldrich. Optical dye (DiI-D282), dihydroethidium (DHE), mitosox red and 4,6-diamidino-2-phenylindole (DAPI-D1306) were purchased from Invitrogen, whereas the (1-ethyl-3-[3-(dimethylamino) propyl] carbodiimide hydrochloride) (EDC) was obtained from Pierce Biotechnology. MES sodium salt was purchased from Acros organic. Apoptosis and necrosis quantification kit was purchased from Biotium and the migration assay kit was purchased from Millipore. The human lung carcinoma cell line A549 (CCL-185) and Chinese hamster cells (CHO) were obtained from ATCC. Magnetic column QuadroMACSTM LS was obtained from Miltinyi Biotec and the dialysis membrane was purchased 
from spectrum laboratories. Dulbecco's modified eagle (DMEM) medium and Kaighn's modification of Ham's F12K medium from Corning.

\section{Instrumentations}

The overall size and zeta potential of nanoparticles were measured using Dynamic light scattering (DLS) instrument, Zetasizer Nano ZS90, from Malvern. Infrared spectra were recorded on a PerkinElmer Spectrum TWO FT-IR spectrometer to confirm the presence of PAA coating. UV/Vis and fluorescence spectra were recorded using Tecan plate reader (Infinite M200PRO). Magnetic relaxation (MR) times (T1 and T2 ms) were measured by using Bruker's benchtop magnetic relaxometer mq20, 0.47T $(\mathrm{B}=20 \mathrm{MHz})$. Fluorescence microscopic images were taken using Olympus IX73 microscope. MTT cell viability study was completed using the TECAN Infinite M200 PRO multi-detection microplate reader.

\section{Synthesis of PAA coated MNPs (1)}

PAA coated magnetic nanoparticles were synthesized by "water-based precipitation method" (Scheme 1). Three solutions were prepared to synthesize PAA coated MNPs. Iron salt solution $(0.75$ $\mathrm{g}$ of $\mathrm{FeCl}_{3} \cdot 6 \mathrm{H}_{2} \mathrm{O}$ and $0.41 \mathrm{~g}$ of $\mathrm{FeCl}_{2} .4 \mathrm{H}_{2} \mathrm{O}$ in dilute $\mathrm{HCl}$ solution $2 \mathrm{M}$ in $\mathrm{DI} \mathrm{H}_{2} \mathrm{O}$ ), an alkaline solution (2 $\mathrm{mL}$ of $30 \% \mathrm{NH}_{4} \mathrm{OH}$ solution in $\mathrm{N}_{2}$-purged $30 \mathrm{~mL}$ deionized water) and stabilizing agent solution (900 $\mathrm{mg}$ of PAA in $5 \mathrm{~mL}$ DI water). The synthetic procedure includes: The addition of the iron salt solution into an alkaline solution with simultaneous vortexing. Then, a stabilizing agent was added and the reaction was continued for $60 \mathrm{~min}$. Thereafter, the resulting MNPs were centrifuged at $4000 \mathrm{rpm}$ for 30 min. The supernatant obtained after the final centrifugation was purified by using QuadroMACSTM magnetic LS column. The concentration of iron in the magnetic nanoparticles was determined using our previously reported "iron digestion method". The presence of negative zeta potential and characteristic acid carbonyl bands on the FTIR spectra confirmed the successful coating of PAA on the magnetic nanoparticles (Figure 2A-2B).

\section{Synthesis of PEGylated MNPs: Carbodiimide chemistry}

To synthesize PEGylated MNPs, $5 \mathrm{~mL}$ of MNP $\left(\mathbf{1},[\mathrm{Fe}]=4.2 \times 10^{-3} \mathrm{~mol}\right)$ suspension was mixed with EDC $(10 \mathrm{mM})$ and mixed for 10 seconds, followed by addition of NHS (10 mM) in MES buffer ( $\mathrm{pH}$ 6.0) and incubated for 3 minute at room temperature on table mixer. Finally, polyethylene glycol, $\mathrm{NH}_{2}$-PEG-COOH $(8 \mathrm{mM})$ in $500 \mu \mathrm{L}$ of $\mathrm{H}_{2} \mathrm{O}$ was added to the reaction mixture drop wise and incubated at room temperature on a table mixer for 4 hours. The resulting PEGylated MNP suspension was purified using dialysis membrane (MWCO 6-8 KDa) and suspended in PBS solution.

\section{Synthesis of propargylated MNPs (3): Carbodiimide chemistry}

For the synthesis of propargylated PAA-MNPs, 4 $\mathrm{mL}$ of PEGylated MNP suspension $(1.0 \mathrm{mM})$ was mixed with EDC (1-ethyl-3-(3- dimethylaminopropyl) carbodiimide hydrochloride) (10 $\mathrm{mM})$, and NHS (2-(N-morpholino) ethanesulfonic acid) $(10 \mathrm{mM})$ in MES buffer ( $\mathrm{pH}$ 6.0) followed by 3 minutes incubation. Finally, propargyl amine $(10 \mathrm{mM})$ in 500 $\mu \mathrm{L}$ of DMSO was added to the reaction mixture drop wise and kept for incubation at room temperature on table mixer for minimum of 4 hours. The resulting propargylated MNP's $\left(3,[\mathrm{Fe}]=3.8 \times 10^{-3} \mathrm{~mol}\right)$ suspension was purified by passing through magnetic column to remove unreacted reagents from the suspension.

\section{Synthesis of folate conjugated MNPs (4a, 5a): "Click" chemistry}

Folate conjugated MNPs were synthesized by adding $4 \mathrm{~mL}$ suspension of propargylated MNPs (3, $\left.[\mathrm{Fe}]=3.8 \times 10^{-3} \mathrm{~mol}\right)$ in PBS $(\mathrm{pH} \mathrm{7.4})$, a catalytic amount of CuI $2 \mu \mathrm{L}(2 \mu \mathrm{M})$ and $500 \mu \mathrm{L}$ of azide functionalized folic acid (Fol $\mathrm{N}_{3}, 3 \times 10^{-2} \mathrm{~mol}$, See SI Scheme S1 for detailed synthesis) with continuous mixing. The final suspension was incubated at room temperature on table mixer for minimum of 5 hours. Finally, the resulting MNPs $(\mathbf{4} \mathbf{a}, \mathbf{5 a}$, Scheme $\mathbf{1})$ were purified by magnetic column to separate unreacted chemicals from the reaction mixture. The purified folate conjugated MNPs $\left([\mathrm{Fe}]=3.1 \times 10^{-3} \mathrm{~mol}\right)$ were characterized by using UV-Visible spectrophotometric measurements. Presence of absorption and fluorescence bands at $360 \mathrm{~nm}$ and $455 \mathrm{~nm}$, respectively, indicated for the successful conjugation of folate ligands on MNPs (Figure 2C \& 2D).

\section{Synthesis of Dil dye-encapsulating functional MNPs (2, 4b): Modified solvent diffusion method}

Dye encapsulation was completed using "modified solvent diffusion method". In this method, we have taken a $2 \mathrm{~mL}$ suspension of corresponding MNPs (1 and 3a, $1.0 \mathrm{mM})$ in PBS (1X, pH = 7.2), and a solution of DiI dye $(1.0 \mu \mathrm{L}, 5 \mu \mathrm{g} / \mu \mathrm{L})$ in $100 \mu \mathrm{L}$ of DMF was added in a drop-wise manner with continuous stirring at $1000 \mathrm{rpm}$ at room temperature. The resulting dye-encapsulating MNPs $(\mathbf{2}, \mathbf{4 b})$ were incubated for $3 \mathrm{~h}$ on a table mixer and purified by passing through magnetic column. UV-Visible spectrophotometric measurements were used to 
confirm the presence of DiI inside the MNPs. Successful encapsulation of DiI was confirmed by presence of absorption and emission peaks at $555 \mathrm{~nm}$ and $585 \mathrm{~nm}$, respectively (Figure 2E \& 2F).

\section{Synthesis and characterization of $\operatorname{Pt}(\mathbf{M C O})_{2}$}

The HMCO cyanoxime was prepared according to the reported procedures, $22,24,52,53$ and characterized by NMR spectroscopy. Platinum complex was obtained from $\mathrm{K}_{2} \mathrm{PtCl}_{4}$ and deprotonated $\mathrm{MCO}^{-}$anion (as $\mathrm{Na}^{+}$salt) using simple two step procedure as shown in SI Scheme S2 and Figure S2. Briefly, $\mathrm{Na}_{2} \mathrm{CO}_{3}$ was added to a stoichiometric amount of $\mathrm{HMCO}$ in $10 \mathrm{~mL}$ of water with intense stirring. A bright-yellow turbid solution of $\mathrm{Na}(\mathrm{MCO})$ was filtered off and resulted in transparent solution of the ligand. Then, $\mathrm{Na}(\mathrm{MCO})(0.195 \mathrm{~g}, 0.954 \mathrm{mmol})$ in $5 \mathrm{~mL}$ of water was added dropwise within one hour to an aqueous solution of $\mathrm{K}_{2} \mathrm{PtCl}_{4}(0.198 \mathrm{~g} ; 0.477 \mathrm{mmol})$ in 5 $\mathrm{mL}$ of water. The reaction mixture became red, but then slowly within $\sim 1 \mathrm{hr}$ gained a green color, and turned to a dark, blue-green, very fine suspension after about five hours. The reaction monitoring is depicted in SI Figure S2. The precipitate was filtered off, washed with $5 \mathrm{~mL}$ of water and dried in a vacuum desiccator charged with c. $\mathrm{H}_{2} \mathrm{SO}_{4}$. The yield of dry dark-green $\mathrm{Pt}(\mathrm{MCO})_{2}$ was $0.152 \mathrm{~g} \quad(76 \%)$. For $\mathrm{C}_{14} \mathrm{H}_{16} \mathrm{~N}_{6} \mathrm{O}_{6} \mathrm{Pt}$ calculated (found), \%: C - 30.06 (29.71), $\mathrm{H}-2.88$ (2.93), $\mathrm{N}-15.02$ (14.82). The solid complex is thermally stable to $\sim 160{ }^{\circ} \mathrm{C}$, not hygroscopic and has a shelf life time over 4 years.

\section{Synthesis of GT, Pt complex and Dil co-encapsulating MNPs (5b)}

To a $2 \mathrm{~mL}$ suspension of MNP-folate in PBS (5a, $\left.[\mathrm{Fe}]=3.1 \times 10^{-3} \mathrm{~mol}\right)$, a solution of $\mathrm{Pt}(10 \mu \mathrm{L}, 5 \mu \mathrm{g} / \mu \mathrm{L})$, GT $(10 \mu \mathrm{L}, 5 \mu \mathrm{g} / \mu \mathrm{L})$ and DiI dye $(1.0 \mu \mathrm{L}, 5 \mu \mathrm{g} / \mu \mathrm{L})$ in $100 \mu \mathrm{L}$ DMF was added drop-wise at 1,000 rpm with continuous stirring. The resulting suspension was incubated at room temperature on table mixer for 60 min. Final suspension was purified by using magnetic column to remove unreacted chemicals and drugs and the final concentration of $5 \mathbf{b}$ was adjusted to $[\mathrm{Fe}]=2.5$ $x 10^{-3} \mathrm{~mol}$. Presence of DiI and Pt complex in the MNPs (5b) were confirmed by using UV-Vis and fluorescence spectrophotometry (Figure 2E and 2F). The encapsulation efficiency was measured using the following equation, EE\% $=[$ (Cargo added - Free "unencapsulated cargo")/Cargo added] x 100, and the measurements were performed using UV-Vis spectroscopy. The $\Delta \mathrm{T} 2$ and $\Delta \mathrm{T} 1 \mathrm{MR}$ data were collected to confirm for effective encapsulation of GT inside MNPs (Figure 3A-3B).

\section{Drug release studies}

Drug release experiments were done by using "dynamic dialysis method". Drug loaded nanoparticles $\left(2.0 \mathrm{~mL},[\mathrm{Fe}]=2.5 \times 10^{-3} \mathrm{~mol}\right)$ were packed in a dialysis bag (MWCO 6-8 KDa) and suspended in PBS solutions (1X) of two different $\mathrm{pH}$ of 7.2 and 6.0 at $37^{\circ} \mathrm{C}$. The aliquot sampled from outer reservoir at regular intervals of time and replaced with same amount of fresh PBS. The absorbance of sample was recorded at $785 \mathrm{~nm}$ for Pt-drug release. The percentage cumulative release was calculated by the following formula.

\section{Cumulative release $(\%)=($ guest $) t /$ (guest)total X 100}

Similarly, MNPs aliquots were collected directly from inside the dialysis bag and both T1 and T2 MR were collected at different time points. (Figure 3C-3E).

\section{Cell viability studies (MTT assay)}

The K-RAS mutant lung carcinoma cells (A549) and Chinese Hamster Ovarian cells $(\mathrm{CHO})$ were obtained from ATCC, USA. Lung carcinoma cells were grown in DMEM medium and $\mathrm{CHO}$ cells were grown in Kaighn's modification of Ham's F12K medium. The medias were prepared by $89 \%$ media supplemented with $10 \%$ Fetal bovine serum (heat-inactivated FBS, Cellgro), 1\% Pen-Strp (penicillin-streptomycin). The cells were maintained at $37{ }^{\circ} \mathrm{C}, 5 \% \mathrm{CO}_{2}$ in a humidified incubator. For MTT assay, A549 cells and CHO cells were seeded in 96-well plates the day before the experiment, next day cells $(2,500$ cells/well) were incubated with the MNPs $\left(30 \mu \mathrm{L},[\mathrm{Fe}]=2.5 \times 10^{-3} \mathrm{~mol}\right)$ for different time periods at $37^{\circ} \mathrm{C}$. Thereafter, each well was washed two times with 1X PBS and added $30 \mu \mathrm{L}$ MTT $(5 \mathrm{mg} / \mathrm{mL})$ solution to each well and incubated at $37^{\circ} \mathrm{C}$ for $4-6 \mathrm{~h}$. The formation of formazan crystals observed within this time limit. The resulting formazan crystals were dissolved in acidified isopropanol $(10 \mathrm{~mL}$ isopropanol $+250 \mu \mathrm{L} \mathrm{c.} \mathrm{HCl}$ ) and the absorbance was recoded at $570 \mathrm{~nm}$ using infinite M200 PRO microplate reader (Figure 4).

\section{Cellular internalization by fluorescence microscopy}

Olympus fluorescence microscope (IX73) was used to establish the internalization mechanism and to observe the progression of the treatment by optical imaging. A549 cell lines and $\mathrm{CHO}$ cell lines were grown in tissue culture dishes $(10,000$ cell/well) and treated as experimental and control cell lines, respectively. The day before the experiment both the cell lines were plated and after $24 \mathrm{~h}$ the cells were treated with different functional nanoparticles $(75 \mu \mathrm{L}$, $\left.[\mathrm{Fe}]=2.5 \times 10^{-3} \mathrm{~mol}\right)$ and incubated in a humidified incubator $\left(37{ }^{\circ} \mathrm{C}\right.$ and $\left.5 \% \mathrm{CO}_{2}\right)$ for $24 \mathrm{~h}$. For internalization mechanism experiments, MNPs (75 $\mu \mathrm{L},[\mathrm{Fe}]=3.1 \times 10^{-3} \mathrm{~mol}$ ) were incubated at low 
temperature $\left(4{ }^{\circ} \mathrm{C}\right)$ and in the presence of inhibitors (10 mM sodium azide and $25 \mathrm{mM} 2$-deoxyglucose). Thereafter, the cells were washed with 1X PBS for two times and fixed by treating with $4 \%$ paraformaldehyde solution for 15 minutes. Cell were then washed with 1X PBS before treating with DAPI dye (6-diamidino-2-phenylindole, $5 \mathrm{mg} / \mathrm{mL}$ ) for 10 minutes to stain cell nuclei. The cell internalization pattern was captured with help of red fluorescence DiI dye and bule DAPI dye using Olympus IX73 fluorescence microscope (Figure 5 and 6).

\section{Determination of mitochondrial and cytosolic ROS in A549 cells}

ROS experiments were performed by using Mitosox red (Mitochondrial ROS tracking dye), dihydroethidium DHE (cytosolic ROS tracking dye) and using a fluorescence microscope. First, A549 cells were plated in cell culture dishes $(10,000$ cell/well) and incubated with different functional MNPs encapsulating different therapeutic drugs $(5 \mathbf{b}, 75 \mu \mathrm{L}$, $[\mathrm{Fe}]=2.5 \times 10^{-3} \mathrm{~mol}$ ) for $3 \mathrm{~h}$ at $37^{\circ} \mathrm{C}$. Similarly, for the inhibition assay, cells were treated in parallel with corresponding functional MNPs and N-acetyl cysteine (3.0 mM, NAC, ROS scavenger) antioxidant for $3 \mathrm{~h}$ at $37^{\circ} \mathrm{C}$. In a separate experiment, folate-MNPs with no drug $\left(5 \mathbf{a}, 75 \mu \mathrm{L},[\mathrm{Fe}]=2.5 \times 10^{-3} \mathrm{~mol}\right)$ was incubated with A549 cells (10,000 cell/well) and used as control experiment. After 3 hours of incubation at $37{ }^{\circ} \mathrm{C}$, the level of mitochondrial ROS and cytosolic ROS generation were assessed by incubating separately with Mitosox red dye $(5 \mu \mathrm{M})$ and with DHE $(32 \mu \mathrm{M})$ dye for about $20 \mathrm{~min}$ at room temperature. Next, cells were washed twice with $1 \mathrm{X}$ PBS and corresponding images for mitochondrial ROS and cytosolic ROS generation were taken by fluorescence microscope using red filter (Figure 7). Quantification of mitochondrial ROS and cytosolic ROS were performed using ImageJ software.

\section{Detection of apoptosis and necrosis in A549 cells by fluorescence microscopy}

Apoptotic and necrotic cells were quantified using fluorescence microscope (Olympus IX73) and apoptosis \& necrosis cell quantification kit (purchased from Biotium). Cells were platted in tissue culture dishes (10,000 cell/well) $24 \mathrm{~h}$ before and treated with functional MNPs $\left(5 \mathbf{b}, 75 \mu \mathrm{L},[\mathrm{Fe}]=2.5 \times 10^{-3} \mathrm{~mol}\right)$ encapsulated with $\mathrm{Pt}$ drug, GT and combination of these two drugs for $12 \mathrm{~h}$, washed for two times with annexin $\mathrm{V}$ binding buffer, and followed by addition of Annexin V-FITC $(5 \mu \mathrm{L})$ and Ethidium homodimer III $(5 \mu \mathrm{L})$ dyes. These dyes were incubated for 15 minutes in dark before fixing the cells using $4 \%$ paraformaldehyde solution, as described in supplier's protocol (Biotium). Finally, washed the cells with annexin $\mathrm{V}$ binding buffer for two times. Images were taken using FITC (green) and CY3 (red) filters of (Olympus) fluorescence microscope. Green images indicate apoptotic cells and red images indicate necrotic cells (Figure 8).

\section{Effect of combination therapy on the inhibition of NSCLC migration}

Migration or invasion capability of A549 cells were quantified using migration assay kit from Millipore and using a plate reader. First, A549 cells were starved for 18-24 h in serum free media. Next day, cells were seeded $(100 \mu \mathrm{L}$ aliquot $)$ along with functional MNPs $\left(20 \mu \mathrm{L},[\mathrm{Fe}]=2.5 \times 10^{-3} \mathrm{~mol}\right)$ with and without the drug combinations into the invasion chamber containing collagen layer and placed on the feeder tray containing serum containing media (150 $\mu \mathrm{L})$. The total setup was placed in an incubator at 37 ${ }^{\circ} \mathrm{C}$ for $24 \mathrm{~h}$ to allow the A549 cells to invade collagen layer. Next day, migrated cells were detached from collagen layer by placing invasion chamber on feeder tray containing cell detachment buffer $(100 \mu \mathrm{L})$ and incubate it for 2-3 h. Next, the detached cells were stained using CyQUANT cell lysis buffer and fluorescence emission signals were recorded using infinite M200 PRO microplate reader at $\lambda_{\mathrm{em}}=560 \mathrm{~nm}$ (Figure 9).

\section{Comet assay}

For conducting comet assay, A549 cells were harvested on a 12 -well plate $(8,000$ cells/well). Next, cells were treated with functional MNPs with and without (control) drugs $\left(5,60 \mu \mathrm{L},[\mathrm{Fe}]=2.5 \times 10^{-3} \mathrm{~mol}\right)$ and incubated for $24 \mathrm{~h}$. Then, cells were trypsinized and centrifuged at 1,000 rpm for $6 \mathrm{~min}$. Cell pellet was resuspended in 1X PBS ( $\mathrm{pH}$ 7.2) and mixed with pre-heated low-melt agarose at 1:10 ratio. This agarose mix $(100 \mu \mathrm{L})$ was applied on to the comet slide. The slide was then initially kept in dark at $4^{\circ} \mathrm{C}$ for $1 \mathrm{~h}$, and subsequently immersed overnight in lysis solution. Alkaline electrophoresis (Trevigen) was conducted on next day following manufacturer's recommended protocol. Briefly, slides were kept in alkaline unwinding solution $(\mathrm{pH}>13)$ and electrophoresis was carried out for $30 \mathrm{~min}$ at $21 \mathrm{~V}$. The slides were then rinsed twice with $\mathrm{DI} \mathrm{H}_{2} \mathrm{O}$ and $70 \%$ ethanol, respectively. Next, slides were stained with SYBR Gold for $15 \mathrm{~min}$ in dark and then dried at $37^{\circ} \mathrm{C}$ for 15 minutes. Finally, images were captured using FITC filter on Olympus IX73 fluorescence microscope (Figure 10).

\section{Conclusion}

In summary, a novel dual-drug carrying 
nanotherapeutics is developed for the treatment of K-RAS driven NSCLC, which is highly metastatic and mostly unresponsive to conventional treatments. We have introduced a new platinum-based antineoplastic therapeutic agent, $\mathrm{Pt}(\mathrm{MCO})_{2}$, to synergize the therapeutic efficacy of Hsp90 inhibitor, ganetespib, for the effective combination therapy of NSCLC. In this study, polyacrylic acid (PAA)-coated magnetic (iron oxide, $\mathrm{Fe}_{3} \mathrm{O}_{4}$ ) nanoparticles (MNPs) were synthesized and used as drug delivery system. These MNPs were decorated with folate receptor-targeting ligand, folic acid, for the targeted delivery of combination drugs to NSCLC. The receptor-mediated internalizations were confirmed by conducting experiments in the presence of various inhibitors and energy factors. We have co-encapsulated dual drugs and an optical dye within the polymer-coating of MNPs using solvent diffusion method. Result from cell viability assay showed minimal toxicity (less than $5 \%$ cell death) for functional MNPs with no therapeutic drug. This result indicated that our formulated functional MNPs are biocompatible. However, folate-decorated MNPs were able to target NSCLC and showed more than $65 \%$ and $90 \%$ cell death within $48 \mathrm{~h}$ of treatment, when carrying single drug and combination of drugs, respectively. These findings indicated that new Pt-drug successfully synergizes the therapeutic efficacy of ganetespib. In addition, the presence of MR imaging modality would be an additional advantage of using magnetic drug delivery system. Furthermore, experiments suggested that the new dual-drug nanomedicine induces apoptosis in NSCLC by generating ROS stress inside the cancerous cells. Results from invasion assay showed that our novel nanotheranostics effectively inhibits the metastatic nature of NSCLC and the comet assay further confirmed the mechanism of action of the dual-drug combination nanomedicine. Taken together, the developed nanotheranostics enhances the therapeutic efficacy of Hsp90 inhibitor drug, ganetespib, by using a novel platinum-based $\mathrm{Pt}(\mathrm{MCO})_{2}$ drug in a combination approach for the effective treatment of NSCLC.

\section{Supplementary Material}

Supplementary figures and tables.

http://www.ntno.org/v03p0120s1.pdf

\section{Acknowledgment}

This project was supported by the National Institute of Health (NIH: 1 R03 AI132832-01) to SS and TB, Kansas INBRE bridging grant (K-INBRE P20 GM103418) and ACS PRF (56629-UNI7) to SS. We thank Prof. Virginia Rider, Department of Biology, PSU, for providing tissue culture facilities.

\section{Competing Interests}

The authors have declared that no competing interest exists.

\section{References}

1. Soria JC, Lee HY, Lee JI, Wang L, Issa JP, Kemp BL, Liu DD, Kurie JM, Mao L, Khuri FR. Lack of PTEN Expression in Non-Small Cell Lung Cancer Could Be Related to Promoter Methylation. Clin Cancer Res. 2002; 8: 1178-1184.

2. Scheffer GL, Pijnenborg ACLM, Smit EF, Muller M, Postma DS, Timens W, Valk P, Vries EGE, Scheper RJ. Multidrug resistance related molecules in human and murine lung. J Clin Pathol. 2002; 55: 332-339.

3. McCarthy JR, Perez JM, Brückner C, Weissleder R. Polymeric nanoparticle preparation that eradicates tumors. Nano Lett. 2005; 5: 2552-2556.

4. Su WP, Cheng FY, Shieh DB, Yeh CS, Su WC. PLGA nanoparticles code liver paclitaxel and Stat 3 siRNA to overcome cellular resistance in lung cancer cells. Int J Nanomed. 2012; 7: 4269-4283.

5. Tassa C, Shaw SY, Weissleder R. Dextran-Coated Iron Oxide Nanoparticles: a Versatile Platform for Targeted Molecular Imaging, Molecular Diagnostics and Therapy. Acc Chem Res. 2011; 44: 842-852

6. Santra S, Jativa SD, Kaittanis C, Normand G, Grimm J, Perez JM. Gadolinium-Encapsulating Iron Oxide Nanoprobe as Activatable NMR/MRI Contrast Agent. ACS Nano. 2012; 6: 7281-7294.

7. Lin W, Huang YW, Zhou XD, Ma Y. Toxicity of Cerium Oxide Nanoparticles in Human Lung Cancer Cells. Int J Toxicol. 2006; 25: 451-457.

8. Baker $\mathrm{CH}$. Harnessing cerium oxide nanoparticles to protect normal tissue from radiation damage. Transl Cancer Res. 2013; 2: 343-358.

9. Jin Y, Kanan S, Wu M, Zhao JX. Toxicity of Luminescent Silica Nanoparticles to Living Cells. Chem Res Toxicol. 2007; 20: 1126-1133.

10. Mann A, Gerasimchuk N, Silchenko S. New non-aggregating bivalent cis-ML2 $(\mathrm{M}=\mathrm{Pd}, \mathrm{Pt} ; \mathrm{L}=$ pivaloylcyanoxime). Inorganica Chimica Acta. 2016; 440: 118-128.

11. Qian Y, Qiu M, Wu O, Tian Y, Zhang Y, Gu N, Li S, Xu L, Yin R. Enhanced cytotoxic activity of cetuximab in EGFR-positive lung cancer by conjugating with gold nanoparticles. Sci Rep. 2014; 4: 1-8.

12. Brown SD, Nativo P, Smith JA, Stirling D, Edwards PR, Venugopal B, Flint DJ, Plumb JA, Graham D, Wheate NJ. Gold Nanoparticles for the Improved Anticancer Drug Delivery of the Active Component of Oxaliplatin. J Am Chem Soc. 2010; 132: 4678-4684.

13. Robertson K, Soto C, Archer M, Odoemene O, Liu J. Engineered T4 Viral Nanoparticles for Cellular Imaging and Flow Cytometry. Bioconjugate Chem. 2011; 22: 595-604.

14. Grasso S, Santi L. Viral nanoparticles as macromolecular devices for new therapeutic and pharmaceutical approaches. Int J Physiol Pathophysiol Pharmacol. 2010; 2: 161-178.

15. Sukumar UK, Bhushan B, Dubey P, Matai I, Sachdev A, Packirisamy G. Emerging applications of nanoparticles for lung cancer diagnosis and therapy. Int Nano Lett. 2013; 3: 1-17.

16. Cho K, Wang X, Nie S, Chen ZG, Shin DM. Therapeutic nanoparticles for drug delivery in cancer. Clin Cancer Res. 2008; 14: 1310-1316.

17. Lee PW, Hsu SH, Wang JJ, Tsai JS, Lin KJ, Wey SP, Chen FR, Lai CH, Yen TC, Sung HW. The characteristics, biodistribution, magnetic resonance imaging and biodegradability of superparamagnetic core-shell nanoparticles. Biomaterials. 2010; 31: 1316-1324.

18. Sundarraj S, Thangam R, Sujitha MV, Vimala K, Kannan S. Ligand-conjugated mesoporous silica nanorattles based on enzyme targeted prodrug delivery system for effective lung cancer therapy. Toxicol Appl Pharmacol. 2014; 275: 232-243.

19. Ma P, Xiao H, Li C, Dai $Y$, Cheng Z, Hou Z, Lin J. Inorganic nanocarriers for platinum drug delivery. Materials Today. 2015; 18: 554-564.

20. Florea AM, Busselberg D. Cisplatin as an Anti-Tumor Drug: Cellular Mechanisms of Activity, Drug Resistance and Induced Side Effects. Cancers. 2011; 3: 1351-1371.

21. Dai Y, Xiao H, Liu J, Yuan O, Ma P, Yang D, Li C, Cheng Z, Hou Z, Yang P, Lin J. In Vivo Multimodality Imaging and Cancer Therapy by Near-Infrared Light-Triggered trans-Platinum Pro-Drug-Conjugated Upconverison Nanoparticles. J Am Chem Soc. 2013; 135: 18920-18929.

22. Eddings D, Barnes C, Gerasimchuk N, Durham P, Domasevich K. First Bivalent Palladium and Platinum Cyanoximates: Synthesis, Characterization, and Biological Activity. Inorg Chem. 2004; 43: 3894-3909.

23. Gerasimchuk N, Goeden L, Durham P, Barnes C, Cannon JF, Silchenko S, Hidalgo I. Synthesis and characterization of disubstituted arylcyanoximes and their several metal complexes. Inorg Chim Acta. 2008; 361: 1983-2001.

24. Ratcliff J, Kuduk-Jaworska J, Chojnacki H, Nemykin V, Gerasimchuk N. Experimental and theoretical studies of 2-cyano-2-isonitroso-N-piperidynylacetamide (HPiPCO), 2-cyano-2-isonitroso-N-morpholylacetamide (HMCO) and their Pt-and Pd-complexes. Inorg Chim Acta. 2012; 385: 1-20.

25. Babu A, Templeton AK, Munshi A, Ramesh R. Nanoparticle based drug delivery for therapy of lung cancer; progress and challenges. J Nanomater. 2013; 2013: 1-11. 
26. Acquaviva J, Smith DL, Sang J, Friedland JC, He S, Sequeira M, Zhang C, Wada Y, Proia DA. Targeting KRAS-Mutant Non-Small Cell Lung Cancer with the Hsp90 Inhibitor Ganetespib. Mol Cancer Therapeutics. 2012; 11: 2633-2643.

27. Proia DA, Sang J, He S, Smith DL, Sequeira M, Zhang C, Liu Y, Ye S, Zhou D, Blackman RK, Foley KP, Koya K, Wada Y. Synergistic activity of the Hsp90 inhibitor ganetespib with taxanes in non-small cell lung cancer models. Investigational New Drugs. 2012; 30: 2201-2209.

28. Yu MK, Jeong YY, Park J, Park S, Kim JW, Min JJ, Kim K, Jon S. Drug-Loaded Superparamagnetic Iron Oxide Nanoparticles for Combined Cancer Imaging and Therapy In Vivo. Angewandte Chemie. 2008; 47: 5442-5445.

29. Santra S, Kaittanis C, Grimm J, Perez JM. Drug/Dye-Loaded, Multifunctional Iron Oxide Nanoparticles for Combined Targeted Cancer Therapy and Dual Optical/Magnetic Resonance Imaging. Small. 2009; 5: 1862-1868.

30. Nath S, Kaittanis C, Ramachandran V, Dalal N. Perez, JM. Synthesis, magnetic characterization and sensing applications of novel dextran-coated iron oxide nanorods. Chem Mater. 2009; 21: 1761-1767.

31. Tromsdorf UI, Bruns OT, Salmen SC, Beisiegel U, Weller H. A Highly Effective, Nontoxic T1 MR Contrast Agent Based on Ultrasmall PEGylated Iron Oxide Nanoparticles. Nano Lett. 2009; 9: 4434-4440.

32. Laurent S, Forge FD, Port M, Roch A, Robic C, Elst LV, Muller RN. Magnetic Iron Oxide Nanoparticles: Synthesis, Stabilization, Vectorization, Physicochemical Characterizations, and Biological Applications. Chem Rev. 2008; 108: 2064-2110.

33. Liu D, Wei L, Ling J, Wen S, Gu N, Zhang X. Effective PEGylation of Iron Oxide Nanoparticles for High Performance In Vivo Cancer Imaging. Adv Funct Mater. 2011; 21: 1498-1504.

34. Sun EY, Josephson L, Weissleder R. "Clickable" nanoparticles for targeted imaging. Mol Imaging. 2006; 5: 122-128.

35. Kolb HC, Finn MG, Sharpless KB. Click Chemistry: Diverse Chemical Function from a Few Good Reactions. Angew Chem Int Ed. 2001; 40: 2004-2021.

36. White MA, Johnson JA, Koberstein JT, Turro NJ. Toward the Syntheses of Universal Ligands for Metal Oxide Surfaces: Controlling Surface Functionality through Click Chemistry. J Am Chem Soc. 2006; 128: 11356-11357.

37. Kaittanis C, Santra S, Santiesteban OJ, Henderson TJ, Perez JM. The assembly state between magnetic nanosensors and their targets orchestrates their magnetic relaxation response. J Am Chem Soc. 2011; 133: 3668-3676.

38. Kaittanis C, Shaffer TM, Ogirala A, Santra S, Perez JM, Chiosis G, Li Y, Josephson L, Grimm J. Environment-responsive nanophores for therapy and treatment monitoring via molecular MRI quenching. Nat Commun. 2014; 5: 3384.

39. Santra S, Jativa SD, Kaittanis C, Normand G, Grimm J, Perez JM. Gadolinium-Encapsulating Iron Oxide Nanoprobes as Activatable NMR/MRI Contrast Agent. ACS Nano. 2012; 6: 7281-7294.

40. Pillai RN, Fennell DA, Kovcin V, et al: Phase 3 study of ganetespib, a heat shock protein 90 inhibitor, with docetaxel versus docetaxel in advanced non-small cell lung cancer (GALAXY-2). 2016 World Conference on Lung Cancer. Abstract 5232. December 6, 2016.

41. Shi XH, Von dem Bussche A, Hurt RH, Kane AB, Gao HJ. Cell entry of one-dimensional nanomaterials occurs by tip recognition and rotation. Nat Nanotechnol. 2011; 6: 714-719.

42. Asati A, Santra S, Kaittanis C, Perez JM. Surface chemistry-dependent cell localization and cytotoxicity of cerium oxide nanoparticles. ACS Nano. 2010; 4: 5321-5331.

43. Porcel E, Liehn S, Remita H, Usami N, Kobayashi K, Furusawa Y, Sech CL, Lacombe S. Platinum nanoparticles: A promising material for future cancer therapy? Nanotechnology. 2010; 21: 1-7.

44. Goldstein S, Meyerstein D, Czapski G. The Fenton reagents. Free Radic Biol Med. 1993; 15: 435-445.

45. Brillas E, Sires I, Oturan MA. Electro-Fenton process and related electrochemical technologies based on Fenton's reaction chemistry. Chem Rev. 2009; 109: 6570-6631.

46. Voinov MA, Pagan JO, Morrison E, Smirnova TI, Smirnov AI. Surface-mediated production of hydroxyl radicals as a mechanism of iron oxide nanoparticle biotoxicity. J Am Chem Soc. 2010; 133: 35-41.

47. Szliszka E, Jaworska D, Klosek M, Czubz ZP, Krol W. Targeting Death Receptor TRAIL-R2 by Chalcones for TRAIL-Induced Apoptosis in Cancer Cells. Int J Mol Sci. 2012; 13: 15343-15359.

48. Brauchle E, Thude S, Brucker SY, Layland KS. Cell death stages in single apoptotic and necrotic cells monitored by Raman micro spectroscopy. Sci Rep. 2014; 4: 1-9.

49. Zhao H, Yang F, Shen W, Wang Y, Li X, You J, Zhou Q. Pazopanib diminishes non-small cell lung cancer (NSCLC) growth and metastases in vivo. Thorac Cancer. 2015; 6: 133-140.

50. Orlow I, Park BJ, Mujumdar U, Patel H, Siu-Lau P, Clas BA, Downey R, Flores $R$, Bains M, Rizk N, Dominguez G, Jani J, Berwick M, Begg CB, Kris MG, Rusch VW. DNA Damage and Repair Capacity in Lung Cancer Patients: Prediction of Multiple Primary Tumors. J Clin Oncol. 2008; 26: 3560-3566.

51. Lundholm L, Haag P, Zong D, Juntti T, Mork B, Lewensohn R, Viktorsson K. Resistance to DNA-damaging treatment in non-small cell lung cancer tumor-initiating cells involves reduced DNA-PK/ATM activation and diminished cell cycle arrest. Cell Death \& Disease. 2013; 4: e478.

52. Cheadle C, Ratcliff J, Berezin M, Pal'shin V, Nemykin VN, Gerasimchuk N. Shortwave infrared luminescent Pt-nanowires: a mechanistic study of emission in solution and in the solid state. Dalton Transactions. 2017; 46: 13562-13581.

53. Klaus DR, Keene M, Silchenko S, Berezin M, Gerasimchuk N. 1D Polymeric Platinum Cyanoximate: A Strategy toward Luminescence in the Near-Infrared Region beyond $1000 \mathrm{~nm}$. Inorganic Chemistry. 2015; 54: 1890-1900. 